Review

\title{
Overview of the Role of Rhizobacteria in Plant Salt Stress Tolerance
}

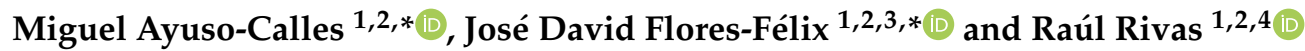 \\ 1 Departamento de Microbiología y Genética, Universidad de Salamanca, Edificio Departamental de Biología, \\ 37007 Salamanca, Spain; raulrg@usal.es \\ 2 Institute for Agribiotechnology Research (CIALE), 37185 Salamanca, Spain \\ 3 CICS-UBI-Health Sciences Research Centre, University of Beira Interior, 6200-506 Covilhã, Portugal \\ 4 Associated Unit University of Salamanca-CSIC (IRNASA), 37008 Salamanca, Spain \\ * Correspondence: miguelac96@usal.es (M.A.-C.); jdflores@usal.es (J.D.F.-F.)
}

Citation: Ayuso-Calles, M.;

Flores-Félix, J.D.; Rivas, R. Overview of the Role of Rhizobacteria in Plant Salt Stress Tolerance. Agronomy 2021, 11, 1759. https://doi.org/10.3390/ agronomy11091759

Academic Editors: Helena Freitas and Rui S. Oliveira

Received: 4 August 2021

Accepted: 30 August 2021

Published: 31 August 2021

Publisher's Note: MDPI stays neutral with regard to jurisdictional claims in published maps and institutional affiliations.

Copyright: (c) 2021 by the authors. Licensee MDPI, Basel, Switzerland. This article is an open access article distributed under the terms and conditions of the Creative Commons Attribution (CC BY) license (https:// creativecommons.org/licenses/by/ $4.0 /)$
Abstract: Salinity is one of the main causes of abiotic stress in plants, resulting in negative effects on crop growth and yield, especially in arid and semi-arid regions. The effects of salinity on plant growth mainly generate osmotic stress, ion toxicity, nutrient deficiency, and oxidative stress. Traditional approaches for the development of salt-tolerant crops are expensive and time-consuming, as well as not always being easy to implement. Thus, the use of plant growth-promoting bacteria (PGPB) has been reported as a sustainable and cost-effective alternative to enhance plant tolerance to salt stress. In this sense, this review aims to understand the mechanisms by which PGPB help plants to alleviate saline stress, including: (i) changes in the plant hormonal balance; (ii) release of extracellular compounds acting as chemical signals for the plant or enhancing soil conditions for plant development; (iii) regulation of the internal ionic content of the plant; or iv) aiding in the synthesis of osmoprotectant compounds (which reduce osmotic stress). The potential provided by PGPB is therefore an invaluable resource for improving plant tolerance to salinity, thereby facilitating an increase in global food production and unravelling prospects for sustainable agricultural productivity.

Keywords: salinity; PGPB; climate change; osmotic stress; ion homeostasis; phytohormones; osmoprotectan; crops

\section{Introduction}

At present, there is scientific consensus indicating that the human production model and energetic consumption are involved in climate change [1]. The impact that this global climatic alteration causes is translated into adverse environmental conditions, such as salinity in soils, extreme temperatures, droughts, or floods, which limit the geographical distribution of plant species and crop yields [2,3]. These types of extreme processes mainly affect semi-arid and arid regions, and they have not only environmental impacts but also economic and social repercussions $[2,4]$.

Soil salinity is the result of the accumulation of soluble salts in soils, due to natural (primary salinization) and/or anthropogenic (secondary salinization) processes, and has been defined as an important cause of loss of soil fertility, as well as agricultural productivity and sustainability [5]. A soil is saline when it presents electrical conductivity (EC) of the saturation extract $\left(\mathrm{EC}_{\mathrm{e}}\right.$ ) of $4 \mathrm{dS} \mathrm{m} \mathrm{m}^{-1}$ (approximately $40 \mathrm{mM} \mathrm{NaCl}$ ) or higher at $25^{\circ} \mathrm{C}$ and has an exchangeable sodium of $15 \%[6,7]$. Although most studies have focused on the effect of $\mathrm{NaCl}$ as a cause of saline stress, in some areas of the planet, this stress is due to the presence of $\mathrm{Na}_{2} \mathrm{SO}_{4}$ [8]. The long-term accumulation of other ions, such as $\mathrm{Ca}^{2+}, \mathrm{Mg}^{2+}$, or $\mathrm{CO}_{3}{ }^{2-}$, has also been shown to have negative effects on plant productivity, when certain thresholds are exceeded [9]. In this sense, it has been estimated that $20 \%$ of cultivated lands and 33\% of irrigated agricultural lands worldwide are affected by salinity $[5-7,10]$. According to the Food and Agriculture Organization (FAO) of the United 
Nations [11,12], and other scientific literature [2,5,13-16], these percentages represent an approximate area of more than 900 million hectares, of which about 77 million hectares could be human-induced salt-affected soils [13]. Furthermore, the rate of lands degraded by salinity increases annually by $10 \%$ due to various factors, such as climate change, poor irrigation practices, and other natural processes $[5,7,10]$.

The impact generated by salinity is predominantly focused in arid and semi-arid regions, where evapotranspiration exceeds precipitation [13,17], although other edaphic, hydrologic, topographic, biological, and anthropogenic factors also interfere in this degradative process [3]. Oceania and Asia are the most-affected continents, as they present $39 \%$ and $34 \%$ of salt-affected soils globally, respectively; this jointly equates to 374 million hectares $[2,11,13]$. Considering human-induced salinization, the percentages in Asia are higher than in the other regions (approximately $70 \%)$, followed by Africa $(20 \%)$ and Europe (5\%) [13]. This degradation of arable land due to salinity has a negative impact on production and, therefore, on the economy. Taking into account studies carried out in India with different crops (rice, wheat, cotton, or sugar cane), production losses due to salt-affected soils may exceed 30\% [18]. Economically, this could represent an annual cost of US\$ 27.3 billion $[2,13,18]$, assuming only losses due to a reduction of crop yield, without counting the additional inputs required to mitigate the impact of saline degradation of soils. However, according to the FAO [12], the annual loss of agricultural productivity has been estimated to be US\$ 31 million, with production losses between $20-40 \%$.

Plants can act through two different strategies to withstand saline stress: On the one hand, through resistance to salinity, consisting of the execution of strategies aimed at reducing the damage caused. On the other hand, through tolerance to salinity, by the reduction of negative fitness impact of damage [19-21]. Crop yield usually decreases when the salt concentration in soils exceeds the salinity threshold $\left(4 \mathrm{dS} \mathrm{m}^{-1}\right)$, although plant species have a huge diversity of tolerance to salt [1]. The effects of salinity on plant growth mainly generate osmotic stress, ion toxicity, nutrient deficiency, and oxidative stress [7]. Firstly, the osmotic phase takes place, due to salt accumulation in the radicular system, thus generating a water deficit in the roots $[2,16,22]$. This osmotic pressure results in a decrease of the growth rate and stomatal closure, with the aim of reducing the water used by the plant $[1,7,16,22]$. This is followed by the ion toxicity phase, which is caused by an excess of ions, mainly $\mathrm{Na}^{+}$and $\mathrm{Cl}^{-}[7,16,23]$. When the salt concentration is high, the accumulation of these ions exceeds the rate of exclusion. This results in an aggregation of radicals in vacuoles and cytoplasm (mainly in leaves), which generates structural and functional alterations of the cell $[1,2,16]$. Furthermore, high salt concentrations can limit macro- $(\mathrm{P}, \mathrm{N})$ and micronutrient uptake (e.g., $\mathrm{Mg}, \mathrm{Fe}, \mathrm{Cu}$, or $\mathrm{Zn}$ ), by reducing their solubility and competing in uptake with $\mathrm{Na}^{+}$and $\mathrm{Cl}^{-}[24,25]$. In turn, osmotic stress and ion toxicity cause a photosynthetic imbalance, which imposes oxidative stress $[1,7,16]$. This metabolic alteration increases the formation of Reactive Oxygen Species (ROS), by-products that affect cellular components, such as photosystems, and which are able to induce programmed cell death $[1,16,22,26]$. Thus, different aspects of plant development, such as germination, vegetative growth, and reproductive development, are disrupted by the actions of all these effects [7].

According to this increasing problem, it is certainly necessary to search for methodologies to provide possible solutions to boost crop yields under salinity. The traditional approach has been based on two main alternatives: appropriate farm management practices and plant breeding $[6,7,17]$. Although sustainable management of the land can ameliorate the effects of soil salinity, it is limited by hydric resources and their quality, and is often slow and costly $[7,17]$. The development of salt-tolerant crops by traditional breeding and transgenic approaches is also an expensive and time-consuming alternative, which is not always easy to implement $[1,17,23]$. Identification of the basic molecular machineries of stress tolerance is a prerequisite for the development of effective varieties, and it is also necessary to increase knowledge in this respect $[6,7,18]$. In contrast, there are other feasible 
and cost-effective strategies, as is the case for the application of beneficial microorganisms that increase salt-tolerance in plants $[1,17,23]$.

In recent years, the application of Plant Growth-Promoting Bacteria (PGPB) has been demonstrated as an effective alternative to enhance plant development and the nutritional content of various crops, even under adverse environmental conditions, such as soil salinity $[10,24,27-31]$. These soil microrganisms are able to improve crop water relations, alter ion homeostasis, or change phytohormone status through direct and indirect mechanisms that modulate abiotic stress regulation $[1,23]$. Therefore, the aim of this review is to understand the mechanisms by which PGPB help plants to alleviate saline stress.

\section{Physiological Effects of Salinity Stress on Plants}

Increased ion concentration in the soil causes salinity. Salt-affected soil includes saline soil, sodic soil, and saline-sodic soil [2]. The common cations associated with salinity are $\mathrm{Na}^{+}, \mathrm{Ca}^{2+}$, and $\mathrm{Mg}^{2+}$, while the common anions are $\mathrm{Cl}^{-}, \mathrm{SO}_{4}{ }^{2-}$, and $\mathrm{HCO}_{3}{ }^{-}$[22] Among them, $\mathrm{Na}^{+}$and $\mathrm{Cl}^{-}$ions are considered the most important, owing to their negative effects in plants and soil $[1,7,16,22]$. The impacts of salinity are complex, ranging from morphological, physiological, and biochemical effects on plants, to erosion and reduced soil productivity $[1,7,22]$. In this sense, soil salinity affects all aspects of plant growth and development (i.e., germination, vegetative growth, and reproductive development) by imposing damaging effects, involving osmotic imbalance and ionic stress. As a consequence of these primary effects, secondary stresses often occur, such as oxidative damage $[1,2,7,16,22]$.

\subsection{Osmotic Stress}

Osmotic stress is a type of stress that occurs when there is an imbalance in the water balance of the plant [32]. It is said to be the first phase in the development of salt stress, which starts immediately after the accumulation of salt above a threshold level around the radicular systems, generating a water deficit in the roots [2,16,32]. Osmotic stress affects shoot and reproductive development: the expansion of leaves is reduced, new leaves emerge more slowly, senescence of older leaves occurs, fewer branches or lateral shoots form, and flowering starts earlier $[1,2,16]$. Radicular system architecture and development is also affected: the elongation of roots is initially diminished, and the formation of lateral roots is repressed $[1,16]$. Furthermore, alteration of the water balance causes stomatal closure and a reduction in gas exchange. All of the above, together with the feedback inhibition of unused photosynthates (which accumulate in plant meristems and storage organs), results in a decrease in the rate of photosynthesis $[1,2,7,16]$.

\subsection{Ionic Stress}

According to the literature, ionic stress is defined as the combination of ion accumulation in plant shoots and an inability to tolerate the ions that have accumulated $[1,2,16]$. The ion toxicity phase is the second stage in the development of salt stress, which appears when the accumulation of these ions exceeds the rate of exclusion. These radicals are transported from the roots to the xylem, through which they move to the leaves, where they accumulate in vacuoles and cytoplasm to toxic levels [1]. Leaves die under these levels of ions and, if the rate of production of new leaves is less than the rate of death, the photosynthetic capacity of the plant is reduced [16]. Moreover, an excess of radical concentration, mainly $\mathrm{Na}^{+}$and $\mathrm{Cl}^{-}$, negatively affects $\mathrm{K}^{+}$uptake, due to competition between the two ions to act as substrate in low-affinity potassium uptake systems, as well as other micronutrients $[1,7,24,25]$. All of this results in structural and functional alterations of the cell: restraint of enzymes involved in photosynthesis and respiration, interference with vesicular trafficking, inhibited cytosolic activities, and/or chloroplast and mitochondrial toxicity $[1,7,16]$. 


\subsection{Oxidative Stress}

Oxidative damage is caused by the production of reactive oxygen species (ROS) in cells, such as singlet oxygen $\left({ }^{1} \mathrm{O}_{2}\right)$, superoxide $\left(\mathrm{O}_{2}{ }^{-}\right)$, hydrogen peroxide $\left(\mathrm{H}_{2} \mathrm{O}_{2}\right)$, or hydroxyl radicals $(\mathrm{OH})[1,16,33]$. ROS are profoundly reactive with cellular components, and induce programmed cell death. They can cause protein and DNA damage, chlorophyll degradation, and lipid peroxidation, consequently affecting photosynthesis and membrane permeability $[1,22,33]$. As previously discussed, osmotic and ionic stress cause photosynthetic imbalances and/or stomatal closure, leading to oxidative damage [16,22].

\section{Main Mechanisms of Salinity Tolerance/Resistance Induced by PGPB}

The physiological effects of salinity cause significant reductions in crop productivity $[1,16]$; however, the application of PGPB has been shown to improve crop productivity, by reducing the physiological damage caused by high ion concentrations in the soil $[1,23]$. This effect is due to different mechanisms exhibited by these beneficial bacteria, which act at different levels, regulating the harmful effects of high salt concentrations $[1,7,23,34,35]$.

\subsection{Osmotic Balance (Water Homeostasis and Osmolyte Accumulation)}

Osmotic stress is the first effect produced by salinity, as previously mentioned. It generates a disruption in the water balance, causing stomatal closure [2,7]. The photosynthesis rate decreases, due to an imbalance in gas exchange and leaf area reduction [1]. Additionally, photosynthate feedback inhibition occurs. The reduction of growth results in an accumulation of carbohydrates in meristems and storage organs, which otherwise would be used in proliferation and the expansion of new tissues [1,23]. Accordingly, plants need to maintain water homeostasis and preserve photosynthetic structures, with the aim to mitigate the impact of salinity. In this sense, the use of PGPB has been demonstrated as an alternative to enhance the osmotic balance, through various mechanisms (see Figure 1, Table 1).

Bacterial extracellular polysaccharides or exopolysaccharides (EPS) are complex hydrated high-molecular weight organic polymers broadly distributed among bacteria [17,36], which have a fundamental roles in the defense of microbiota against stressful environmental conditions ( $\mathrm{pH}$ or temperature), as well as adhesion to biotic and abiotic surfaces [37]. The composition and amount of ESP depend on the strain and conditions [34]. ESP also have additional functions in plant-microbe interactions. The addition of polysaccharides increases the adherence of soil particles into microaggregates and favors macropore generation, which are beneficial in improving porosity and aeration in soil (Figure 1) $[17,23,38,39]$. Thus, the effects of the initial osmotic stress are diminished by binding soil particles and improving its structure [7]. It has been shown that co-inoculation of the plant growthpromoting rhizobacteria Pseudomonas mendocina and the arbuscular mycorrhizal fungus Glomus intraradices onto lettuce resulted in a high percentage of stable aggregates in soil under field conditions, due to the bacterial EPS production [40]. Moreover, according to Qurashi \& Sabri [41], the effect of inoculating two bacterial strains, Halomonas variabilis HT1 and Planococcus rifietoensis RT4, onto Cicer arietinum plants subject to soil aggregation under salt stress led to enhancements in chickpea growth and soil structure.

As previously stated, salinity causes growth reduction and feedback inhibition of unused photosynthates. Microorganisms can modulate the source-sink relationships of soluble sugars in plants, favoring osmotic adjustment and avoiding feedback photoinhibition during the salinity osmotic phase (Figure 1) [1,42]. On one hand, plant roots are a strong carbohydrate sink, and their development can be mediated by the hormonal response (IAA) associated with the action of the microbe. On the other hand, the microbes can also consume a considerable part of these photosynthates [23]; for example, the salt resistance of two nodulated Medicago ciliaris L. lines was mediated by the maintenance of nodular-symbiotic and source-sink activities [43]. In addition, co-inoculation of Bradyrhizobium japonicum 532C, Rhizobium sp. SL42, and Hydrogenophaga sp. SL48 onto soybean plants under saline conditions improved shoot and root growth, nitrogen assimilation, and 
the $\mathrm{K}^{+} / \mathrm{Na}^{+}$ratio, which could be a consequence of nodular-symbiotic and source-sink activities [44]. Capsicum annuum L. plants co-inoculated with Azospirillum brasilense M3 and Pantoea dispersa C 3 under salinity $(40-120 \mathrm{mM} \mathrm{NaCl})$ showed increases in analyzed production parameters, as related to higher stomatal conductance and photosynthesis, without changes in chlorophyll content or photosystem efficiency [45]. In the same way, inoculation with various Bacillus strains in strawberry and wheat has increased different leaf physiological parameters, such as photosynthesis or stomatal conductance [46], or productivity and nutritional content [47].

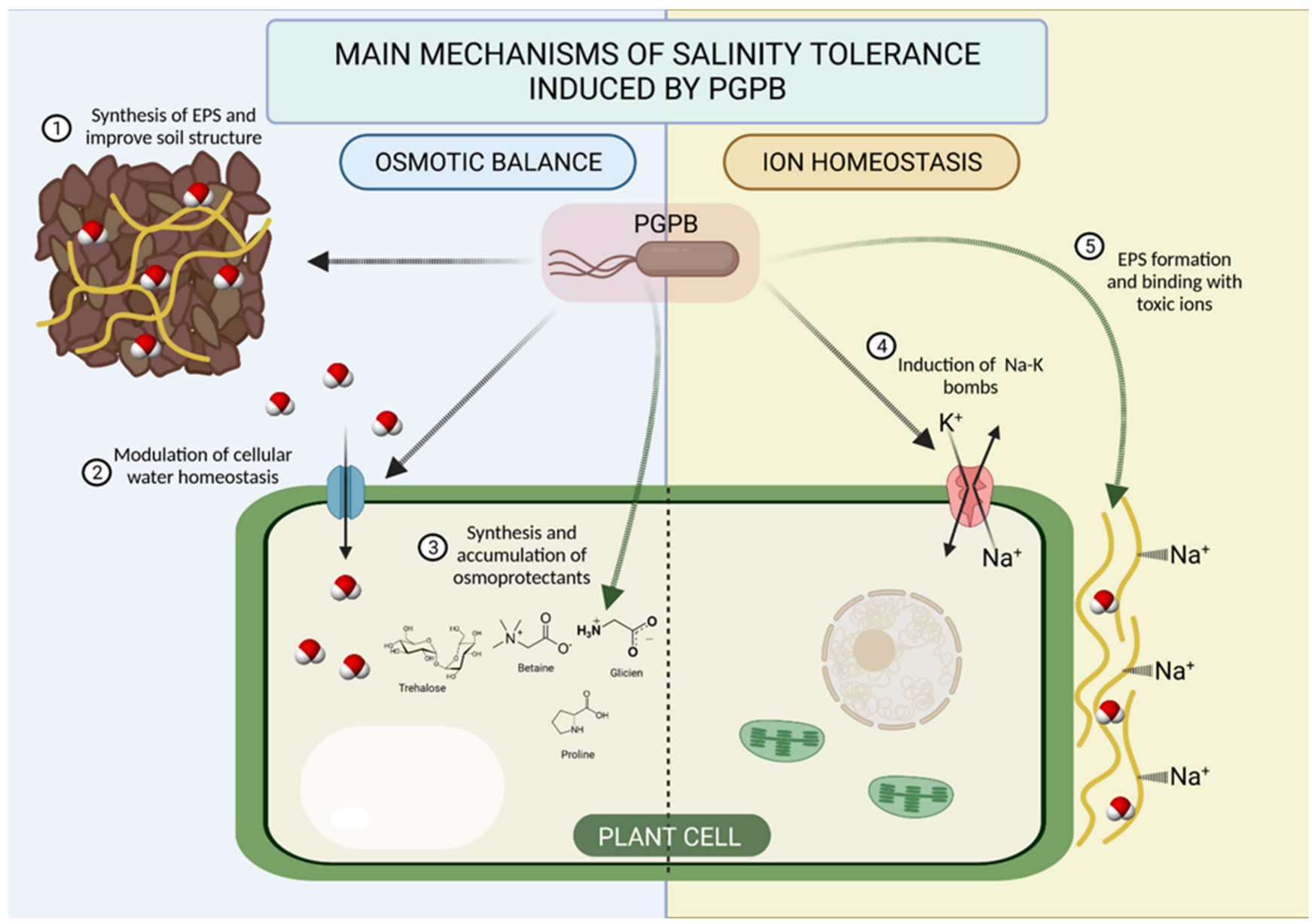

Figure 1. Main mechanisms of salinity stress tolerance induced by Plant Growth Promoting Bacteria.

Saline stress causes a loss of intracellular water in plants [48]. Therefore, vegetal species accumulate organic osmolytes in the cytoplasm, in order to maintain the osmotic cellular state and to improve their response to such stress [34,48]. These compounds include proline, glycine, betaine, or trehalose, among others (Figure 1) $[1,23,48]$. Salt-tolerant bacteria also employ this mechanism against osmotic fluctuations of the environment [34]. In addition, the biosynthesis of such osmoprotectans is quicker in bacteria than in their associated plants [1]. It has been observed that inoculation with PGPB generated an improvement of osmolytes in plants, which may be due to bacterial solutes being taken up by the roots or de novo synthesis in plants, where the PGPB have been demonstrated to be useful [1,23]. The accumulation of certain osmoprotectans (e.g., proline, betaine) has helped various vegetal species to resist salt-stress conditions in the presence of beneficial bacterial strains, such as Burkholderia [49,50], Arthrobacter [51], Azospirillum [52], Bacillus [51,53], Rhizobium, and Pseudomonas [24]. Similarly, Oryza sativa L. inoculated with Pseudomonas pseudoalcaligenes $\mathrm{YJ} 1$ has shown the accumulation of glycine betaine-like quaternary compounds, while co-inoculation with P. pseudoalcaligenes YJ1 and Bacillus pumilus YJ2 was also 
able to protect the plant from salinity [54]. It has also been shown that the use of three bacterial strains (B. megaterium MPP7, B. tequilensis MPP8, and P. putida MPP18) increased the production of proline and total soluble sugar in salt-stressed wheat plants, which also reduced electrolytic leakage and enhanced enzymatic activity for the scavenging of reactive oxygen species (ROS) [55]. In this sense, pea plant grown under salinity stress and inoculated with various PGPR (Acinetobacter bereziniae IG2, Enterobacter ludwigii IG10, and Alcaligenes faecalis IG27) showed higher proline and total soluble sugar content, as well as a reduction in oxidative damage [56]. Furthermore, the construction of Pseudomonas strain mutants for the gene coding trehalose synthase (treS) has been carried out, and the function of this bacterial mechanism in the protection of a plant (tomato) against salt stress has been reported [57].

The plant water potential is altered under high salt concentration conditions. PGPB can regulate water homeostasis by improving the hydraulic conductivity (Figure 1) [1,23,58]. Inoculation with Bacillus megaterium B26 in maize plants under salinity $\left(2.59 \mathrm{dS} \mathrm{m} \mathrm{m}^{-1}\right.$ ) generated an enhancement in the hydraulic conductance, as related to a positive regulation of PIP-type plasma membrane aquaporins [59]. This same effect has also been observed in tropical corn plants exposed to salt stress $(200 \mathrm{mM} \mathrm{NaCl})$ and inoculated with Pantoea agglomerans SG_JW.01 rhizobacteria [60]. Furthermore, Azospirillum brasilense AZ39 inoculation produced improvements in a PIP-type aquaporin transcription for barley plants grown under saline conditions (200 $\mathrm{mM} \mathrm{NaCl})$ [61].

Table 1. PGPB-produced mechanisms related to tolerance against salinity stress.

\begin{tabular}{|c|c|c|c|c|}
\hline Bacteria & Plant & Mechanism & Effect & Reference \\
\hline \multicolumn{5}{|c|}{ Osmotic balance } \\
\hline Pseudomonas mendocina & Lactuca sativa $\mathrm{L}$. & EPS production & $\begin{array}{l}\text { High percentage of stable soil } \\
\text { aggregates }\end{array}$ & {$[40]$} \\
\hline $\begin{array}{l}\text { Halomonas variabilis and } \\
\text { Planococcus rifietoensis }\end{array}$ & Cicer arietinum $\mathrm{L}$. & $\begin{array}{l}\text { Biofilm formation and EPS } \\
\text { production }\end{array}$ & $\begin{array}{l}\text { Increased plant growth under } \\
\text { salinity and soil aggregation }\end{array}$ & [41] \\
\hline Sinorhizobium medicae & Medicago ciliaris L. & $\begin{array}{l}\text { Nodulation and bacterial } \\
\text { source-sink activities }\end{array}$ & $\begin{array}{l}\text { Differential carbohydrate and } \\
\text { hormonal changes between } \\
\text { source-sink tissues }\end{array}$ & [43] \\
\hline $\begin{array}{l}\text { Bradyrhizobium } \\
\text { japonicum, Rhizobium sp. } \\
\text { and Hydrogenophaga sp. }\end{array}$ & Glycine max L. & $\begin{array}{l}\text { Nodulation and bacterial } \\
\text { source-sink activities }\end{array}$ & $\begin{array}{c}\text { Improved shoot and root } \\
\text { growth, nitrogen assimilation, } \\
\text { and } \mathrm{K}^{+} / \mathrm{Na}^{+} \text {ratio }\end{array}$ & {$[44]$} \\
\hline $\begin{array}{l}\text { Azospirillum brasilense } \\
\text { and Pantoea dispersa }\end{array}$ & Capsicum annuum L. & $\begin{array}{l}\text { Maintaining of higher } \\
\text { stomatal conductance }\end{array}$ & $\begin{array}{l}\text { Higher dry weight and } \\
\mathrm{K}^{+} / \mathrm{Na}^{+} \text {ratio }\end{array}$ & [45] \\
\hline $\begin{array}{l}\text { Bacillus licheniformis, } \\
\text { Bacillus subtilis, and } \\
\text { Bacillus sp. }\end{array}$ & Fragaria $\mathrm{x}$ ananassa & $\begin{array}{l}\text { Maintaining of higher } \\
\text { stomatal conductance and } \\
\text { transpiration rate }\end{array}$ & $\begin{array}{l}\text { Enhanced growth, yield, and } \\
\text { fruit quality }\end{array}$ & [46] \\
\hline Bacillus aquimaris & Triticum aestivum L. & $\begin{array}{l}\text { Accumulation of } \\
\text { osmoprotectans (proline } \\
\text { and soluble sugars) }\end{array}$ & $\begin{array}{l}\text { Increased biomass, weight, } \\
\text { and leaf nutrients }\end{array}$ & [47] \\
\hline $\begin{array}{l}\text { Burkholderia } \\
\text { phytofirmans }\end{array}$ & Vitis vinifera $\mathrm{L}$. & Bacterial colonization & $\begin{array}{l}\text { Higher root growth and } \\
\text { plantlet biomass }\end{array}$ & {$[50]$} \\
\hline $\begin{array}{l}\text { Arthrobacter sp. and } \\
\text { Bacillus sp. }\end{array}$ & Capsicum annuum L. & $\begin{array}{c}\text { Accumulation of } \\
\text { osmoprotectans (proline) } \\
\text { and transcriptional } \\
\text { changes }\end{array}$ & Increased fresh biomass & [51] \\
\hline Azospirillum brasilense & Zea mays L. & $\begin{array}{c}\text { Accumulation of } \\
\text { osmoprotectans (trehalose) }\end{array}$ & $\begin{array}{l}\text { Increased survival, leaf and } \\
\text { root biomass }\end{array}$ & {$[52]$} \\
\hline $\begin{array}{c}\text { Bacillus spp. and } \\
\text { Paenibacillus favisporus }\end{array}$ & Zea mays L. & $\begin{array}{l}\text { Accumulation of } \\
\text { osmoprotectans (proline } \\
\text { and sugars) }\end{array}$ & $\begin{array}{c}\text { Increased plant biomass, water } \\
\text { homeostasis, and soil } \\
\text { aggregate stability }\end{array}$ & [53] \\
\hline
\end{tabular}


Table 1. Cont.

\begin{tabular}{|c|c|c|c|c|}
\hline Bacteria & Plant & Mechanism & Effect & Reference \\
\hline $\begin{array}{l}\text { Rhizobium sp. and } \\
\text { Pseudomonas sp. }\end{array}$ & Zea mays L. & $\begin{array}{c}\text { Accumulation of } \\
\text { osmoprotectans (proline), } \\
\text { ion and water homeostasis }\end{array}$ & $\begin{array}{l}\text { Enhanced plant development, } \\
\text { biomass, and nutrient uptake }\end{array}$ & [24] \\
\hline $\begin{array}{c}\text { Pseudomonas } \\
\text { pseudoalcaligenes and } \\
\text { Bacillus pumilis }\end{array}$ & Oryza sativa L. & $\begin{array}{c}\text { Accumulation of } \\
\text { osmoprotectans (glycine } \\
\text { betaine-like compounds) }\end{array}$ & $\begin{array}{l}\text { Higher plant weight and } \\
\text { height }\end{array}$ & [54] \\
\hline $\begin{array}{l}\text { Bacillus megaterium, } \\
\text { Bacillus tequilensis, and } \\
\text { Pseudomonas putida }\end{array}$ & Triticum aestivum $\mathrm{L}$. & $\begin{array}{l}\text { Accumulation of } \\
\text { osmoprotectans (proline } \\
\text { and soluble sugars) and } \\
\text { transcriptional changes in } \\
\text { ion transporter genes } \\
\text { (SOS-type) }\end{array}$ & $\begin{array}{l}\text { Reduced electrolytic leakage } \\
\text { and oxidative damage }\end{array}$ & [55] \\
\hline $\begin{array}{l}\text { Acinetobacter bereziniae, } \\
\text { Enterobacter ludwigii, } \\
\text { and Alcaligenes faecalis }\end{array}$ & Pisum sativum $\mathrm{L}$. & $\begin{array}{l}\text { Accumulation of } \\
\text { osmoprotectans (proline } \\
\text { and soluble sugars) }\end{array}$ & Reduced oxidative damage & [56] \\
\hline Pseudomonas sp. & Solanum lycopersicum L. & $\begin{array}{c}\text { Accumulation of } \\
\text { osmoprotectans (trehalose) } \\
\text { and ACC deaminase } \\
\text { production }\end{array}$ & $\begin{array}{l}\text { Higher root and shoot length, } \\
\text { total dry weight, and } \\
\text { chlorophyll content }\end{array}$ & [57] \\
\hline Bacillus megaterium & Zea Mays L. & $\begin{array}{l}\text { Upregulation of aquoporin } \\
\text { genes (PIP-type) }\end{array}$ & $\begin{array}{l}\text { Higher root hydraulic } \\
\text { conductance }\end{array}$ & [59] \\
\hline Pantoea agglomerans & $\begin{array}{c}\text { Dracaena fragrans (L.) } \\
\text { KER GAWL. }\end{array}$ & $\begin{array}{l}\text { Upregulation of aquoporin } \\
\text { genes (PIP-type) }\end{array}$ & Increased dry biomass & [60] \\
\hline Azospirillum brasilense & Hordeum vulgare L. & $\begin{array}{l}\text { Upregulation of aquoporin } \\
\text { genes (PIP-type) }\end{array}$ & Increased biomass and height & {$[61]$} \\
\hline \multicolumn{5}{|c|}{ Ion homeostasis } \\
\hline Bacillus subtilis & $\begin{array}{l}\text { Puccinellia tenuiflora } \\
\text { SCRIBN. \& MERR. }\end{array}$ & $\begin{array}{l}\text { Transcriptional changes in } \\
\text { ion transporter genes } \\
\text { (HKT-type) }\end{array}$ & $\begin{array}{l}\text { Decreased } \mathrm{Na}^{+} \text {accumulation } \\
\text { and increased shoot and root } \\
\text { growth }\end{array}$ & [62] \\
\hline Kocuria rhizophila & Zea mays L. & $\begin{array}{l}\text { Transcriptional changes in } \\
\text { ion transporter genes (HKT } \\
\text { and NHX-type) and } \\
\text { hormonal changes (IAA } \\
\text { and ABA) }\end{array}$ & $\begin{array}{c}\text { Decreased } \mathrm{Na}^{+} \text {accumulation } \\
\text { and increased productivity } \\
\text { parameters }\end{array}$ & [63] \\
\hline Pseudomonas simiae & Glycine $\max \mathrm{L}$. & $\begin{array}{l}\text { Transcriptional changes in } \\
\text { phosphatase activity, } \\
\text { accumulation of } \\
\text { osmoprotectans (proline), } \\
\text { and VOCs production }\end{array}$ & $\begin{array}{l}\text { Higher weight, length, and } \\
\qquad \mathrm{K}^{+} / \mathrm{Na}^{+} \text {ratio }\end{array}$ & {$[64]$} \\
\hline Pseudomonas mendocina & Lactuca sativa $\mathrm{L}$. & $\begin{array}{l}\text { Transcriptional changes in } \\
\text { phosphatase activity and } \\
\text { accumulation of } \\
\text { osmoprotectans (proline) }\end{array}$ & $\begin{array}{l}\text { Increased biomass and water } \\
\text { content }\end{array}$ & [65] \\
\hline $\begin{array}{l}\text { Brachybacterium sp., } \\
\text { Brevibacterium sp. and } \\
\text { Haererohalobacter } \mathrm{sp} .\end{array}$ & Arachis hypogaea L. & $\begin{array}{l}\text { Water homeostasis and } \\
\text { IAA plant accumulation }\end{array}$ & $\begin{array}{l}\text { Higher productivity variables } \\
\text { and nutrient content }\end{array}$ & [66] \\
\hline Pseudomonas putida & Gossypium hirsutum L. & $\begin{array}{c}\text { Hormonal changes (IAA } \\
\text { and ABA) }\end{array}$ & $\begin{array}{c}\text { Increased germination rate, } \\
\text { productivity variables, and } \\
\text { nutrient content }\end{array}$ & [67] \\
\hline Azotobacter chroococcum & Zea mays L. & $\begin{array}{l}\text { Hormonal changes and } \\
\text { accumulation of } \\
\text { polyphenols }\end{array}$ & $\begin{array}{l}\text { Higher plant length, weight, } \\
\text { and ion uptake }\end{array}$ & [68] \\
\hline Azospirillum brasilense & Zea mays L. & $\begin{array}{l}\text { Transcriptional changes in } \\
\text { plant growth genes }\end{array}$ & Higher $\mathrm{K}^{+} / \mathrm{Na}^{+}$ratio & [69] \\
\hline
\end{tabular}


Table 1. Cont.

\begin{tabular}{|c|c|c|c|c|}
\hline Bacteria & Plant & Mechanism & Effect & Reference \\
\hline $\begin{array}{l}\text { Rhizobium sp. and } \\
\text { Pseudomonas sp. }\end{array}$ & Zea mays L. & $\begin{array}{c}\text { Accumulation of } \\
\text { osmoprotectans (proline), } \\
\text { ion and water homeostasis }\end{array}$ & $\begin{array}{l}\text { Enhanced plant development, } \\
\text { biomass, and nutrient uptake }\end{array}$ & [24] \\
\hline $\begin{array}{l}\text { Aeromonas sp. and } \\
\text { Bacillus spp. }\end{array}$ & Triticum aestivum $\mathrm{L}$. & EPS production & $\begin{array}{l}\text { Increased growth parameters, } \\
\mathrm{K}^{+} / \mathrm{Na}^{+} \text {ratio, and soil } \\
\text { aggregation an }\end{array}$ & [70] \\
\hline $\begin{array}{l}\text { Bacillus subtilis and } \\
\text { Marinobacter lipolyticus }\end{array}$ & Triticum aestivum $\mathrm{L}$. & EPS production & $\begin{array}{c}\text { Increased growth parameters, } \\
\mathrm{K}^{+} / \mathrm{Na}^{+} \text {ratio, and selective } \\
\text { nutrient uptake }\end{array}$ & [71] \\
\hline Pseudomonas mendocina & Lactuca sativa $\mathrm{L}$. & $\begin{array}{l}\text { EPS production, } \\
\text { accumulation of } \\
\text { osmoprotectans (proline), } \\
\text { and raised antioxidant } \\
\text { enzyme activities }\end{array}$ & $\begin{array}{l}\text { Higher shoot biomass, water } \\
\text { content, and } \mathrm{K}^{+} / \mathrm{Na}^{+} \text {ratio }\end{array}$ & [72] \\
\hline $\begin{array}{l}\text { Pseudomonas sp. and } \\
\text { Bacillus sp. }\end{array}$ & Glycine max L. & $\begin{array}{l}\text { ESP, ACC deaminase and } \\
\text { IAA production, and } \\
\text { accumulation of } \\
\text { osmoprotectans (proline) }\end{array}$ & $\begin{array}{c}\text { Enhanced plant biomass, water } \\
\text { content, and photosynthesis } \\
\text { activity }\end{array}$ & [73] \\
\hline $\begin{array}{l}\text { Halomonas maura and } \\
\text { Ensifer meliloti }\end{array}$ & Medicago sativa L. & $\begin{array}{l}\text { Nodulation and EPS } \\
\text { production }\end{array}$ & $\begin{array}{c}\text { Increased plant biomass and } \\
\text { leghaemoglobin }\end{array}$ & [74] \\
\hline $\begin{array}{l}\text { Staphylococcus sciuri, } \\
\text { Zobellella denitrificans, } \\
\text { and Arthrobacter } \\
\text { endophyticus }\end{array}$ & Pistacia vera $\mathrm{L}$. & EPS production & $\begin{array}{c}\text { Increased productivity } \\
\text { parameters, and } \mathrm{K}^{+} / \mathrm{Na}^{+} \text {ratio }\end{array}$ & [75] \\
\hline Bacillus aquimaris & Triticum aestivum $\mathrm{L}$. & $\begin{array}{l}\text { Accumulation of } \\
\text { osmoprotectans (proline } \\
\text { and soluble sugars) }\end{array}$ & $\begin{array}{l}\text { Increased biomass, weight, } \\
\text { and leaf nutrients }\end{array}$ & [47] \\
\hline
\end{tabular}

\subsection{Ion Homeostasis (Regulation of Ion Content)}

Salinity causes $\mathrm{Na}^{+}, \mathrm{Cl}^{-}, \mathrm{Ca}^{2+}, \mathrm{Mg}^{2+}, \mathrm{SO}_{3}{ }^{2-}$, or $\mathrm{CO}_{3}{ }^{2-}$ accumulation, which results in the ion toxicity phase. Ionic stress occurs under prolonged exposure to high salt concentrations, when the influx of these ions overcomes the rate of exclusion $[1,16]$. Plants initially compartmentalize the excessive salts in vacuoles, avoiding their accumulation in the cytosol and intracellular spaces, which limits photosynthesis and respiration [1]. Elevated $\mathrm{Na}^{+}$concentrations affect $\mathrm{K}^{+}$-dependent process, where the replacement of $\mathrm{K}^{+}$by $\mathrm{Na}^{+}$in biochemical reactions results in protein conformation changes and synthesis $[7,76]$. It has also been observed that there is a dependence between the reduction of productivity and the ionic balance, determined by the $\mathrm{K}^{+}: \mathrm{Na}^{+}, \mathrm{Mg}^{2+}: \mathrm{Na}^{+}$, and $\mathrm{Ca}^{2+}: \mathrm{Na}^{+}$ratios [9]. Soil micro-organisms have been reported to maintain ion homeostasis, which must benefit plant growth and tolerance during salinity [23,77]; however, these studies have focused on $\mathrm{NaCl}$ saline stress, but not other ions involved in saline stress.

Maintaining a high $\mathrm{K}^{+} / \mathrm{Na}^{+}$ratio is one of the ways by which PGPB can regulate toxic ion homeostasis, thus reducing the accumulation of $\mathrm{Na}^{+}$and $\mathrm{Cl}^{-}$in leaves, boosting ion exclusion by the root, or modulating the expression of ion transporters [1,23]. High-affinity $\mathrm{K}^{+}$transporters (HKT) are plasma membrane proteins that mediate $\mathrm{Na}^{+}$transport in plants, preventing the build-up of high concentrations of $\mathrm{Na}$ ions in shoots by excluding to the roots (Figure 1) [49,76]. It has been shown that inoculation with rhizobacteria modulates the expression of these types of transporters. The B. subtilis GB03 strain conferred salt tolerance Puccinellia tenuiflora Scribn. \& Merr., by enhancing selective absorption of $\mathrm{K}^{+}$ over $\mathrm{Na}^{+}$and (down- and up-)regulating the expression of HKT-family genes in roots and shoots, such as HKT1 or HKT2 [62]. Furthermore, the expression of ion affinity transporters (ZmHKT1, ZmNHX1, ZMNHX2, and ZmNHX3) has also been up-regulated in Zea mays L. after exposure to salt stress and inoculation with Kocuria rhizophila Y1, resulting in protection of the plant against salinity [63]. Thus, tissue-specific regulation of HKT-type 
genes in plant-microbe interactions is necessary for toxic ion homeostasis in salt-stressed plants $[49,62,76]$. Moreover, there are other enzymes that act as sodium antiporters, such as Salt Overlay Sensitive (SOS) genes, which can help the plants to cope with salinity stress [55]. In this sense, inoculation with three bacterial strains (B. megaterium MPP7, $B$. tequilensis MPP8, and P. putida MPP18) on wheat plants grown under saline conditions revealed the higher expression of SOS1 and SOS4 genes, which were associated with a higher relative water content and photosynthetic pigments in wheat seedlings [55].

PGPB can also reduce the accumulation of $\mathrm{Na}^{+}$and $\mathrm{Cl}^{-}$ions, by regulating the exchange of macro- and micro-nutrients [1]. First, microbial activities, such as $\mathrm{P}_{\mathrm{i}}$ (inorganic phosphate) solubilization or siderophore production, may make these nutrients more accessible to plants (Figure 1) [23,77]. Second, inoculation with PGPB can induce the up-regulation of proteins related to phosphatase activity (associated with $\mathrm{P}_{\mathrm{i}}$ solubilization). As Vaishnav et al. [64] have reported, Pseudomonas simiae AU treatment in soybean plants under salt stress increased the expression of VSP (vegetative storage protein) in plants, which had preponderant roles in acid phosphatase activity. In this sense, water-stressed lettuce plants colonised by the Pseudomonas mendocina Palleroni strain also increased acid phosphatase activity, among other effects, thus alleviating oxidative stress in plants [65]. Three bacterial strains, belonging to Brachybacterium, Brevibacterium, and Haererohalobacter genera, improved productivity variables of peanut plants under $100 \mathrm{mM} \mathrm{NaCl}$, as well as $\mathrm{K}^{+} / \mathrm{Na}^{+}$ratio and $\mathrm{Ca}^{2+}$, phosphorus, and nitrogen content [66]. Moreover, a P. putida strain increased the absorption of $\mathrm{Mg}^{2+}, \mathrm{K}^{+}$, and $\mathrm{Ca}^{2+}$ in cotton plants grown under saline conditions ( $3.5 \mathrm{~g}$ salt $/ \mathrm{kg}$ soil), and decreased the uptake of $\mathrm{Na}^{+}$; plant growth was also enhanced after its application [67]. According to Rojas-Tapias et al. [62], maize plants grown under saline conditions (2.93 and $5.85 \mathrm{~g} \mathrm{NaCl} / \mathrm{kg}$ soil) and treated with two Azotobacter chroococcum strains showed an enhancement in $\mathrm{Na}^{+}$exclusion and $\mathrm{K}^{+}$uptake, as well as polyphenol and chlorophyll content, with respect to uninoculated controls. Another free-living nitrogen-fixing rhizobacteria also significantly improved the $\mathrm{K}^{+} / \mathrm{Na}^{+}$ratio in a salt-sensitive maize cultivar, by restricting $\mathrm{Na}^{+}$uptake and selectively increasing $\mathrm{K}^{+}$ and $\mathrm{Ca}^{2+}$ [69]. In addition, $\mathrm{NaCl}$-affected maize $(100 \mathrm{mM})$, co-inoculated with Rhizobium and Pseudomonas, exhibited some positive adaptative responses to such stress, such as an increase in proline content or the selective absorption of $\mathrm{K}^{+}$ions [24].

Exopolysaccharide (EPS) production also provides a way in which microbes can reduce the uptake of toxic ions in plants. These compounds act as a physical barrier around the root system, preventing the effects of the ion toxicity phase $[17,35,77]$. EPS bind cations, including $\mathrm{Na}^{+}$, and thereby decrease the accessibility of toxic ions available for plant uptake, reducing the salinity stress by diminishing its transfer to leaves (Figure 1) $[7,17,23,35]$. According to Ashraf et al. and Talebi Atouei et al. [70,71], wheat plants affected by salinity and treated with EPS-producing bacteria showed increases in growth parameters and alteration of nutrient uptake, by diminishing $\mathrm{Na}^{+}$concentration and boosting the absorption of $\mathrm{K}^{+}$and $\mathrm{Ca}^{2+}$. Similarly, a plant growth-promoting rhizobacteria (P. mendocina), in combination with an arbuscular mycorrhizal fungus (G. intraradices), colonised lettuce plants, which presented higher concentrations of foliar $\mathrm{K}^{+}$and lower amounts of $\mathrm{Na}^{+}$ under saline conditions [72]. The inoculation with other exopolysaccharide-producing rhizobacteria also indicated the important role that they play in alleviating saline stress conditions in different crops, such as soybean, wheat, alfalfa, or pistachio $[47,73-75]$.

\section{Molecules Synthesized by Rhizobacteria Involved in Tolerance/Resistance to Osmotic Stress}

\subsection{Synthesis of Phytohormones}

Phytohormones are synthesized by plants in response to salt stress, such as indole-3acetic acid (IAA), abscisic acid (ABA), or ethylene. These substances alter plant metabolism, morphology, biomass production, and other mechanisms [23,77]. Moreover, soil bacteria may directly alter the plant hormonal balance, by producing exogenous phytohormones. Thus, changes in hormonal signalling arising from plant-microbe interactions are considered as a mechanism for plant soil salinity tolerance (Figure 2) [1,23,77]. 


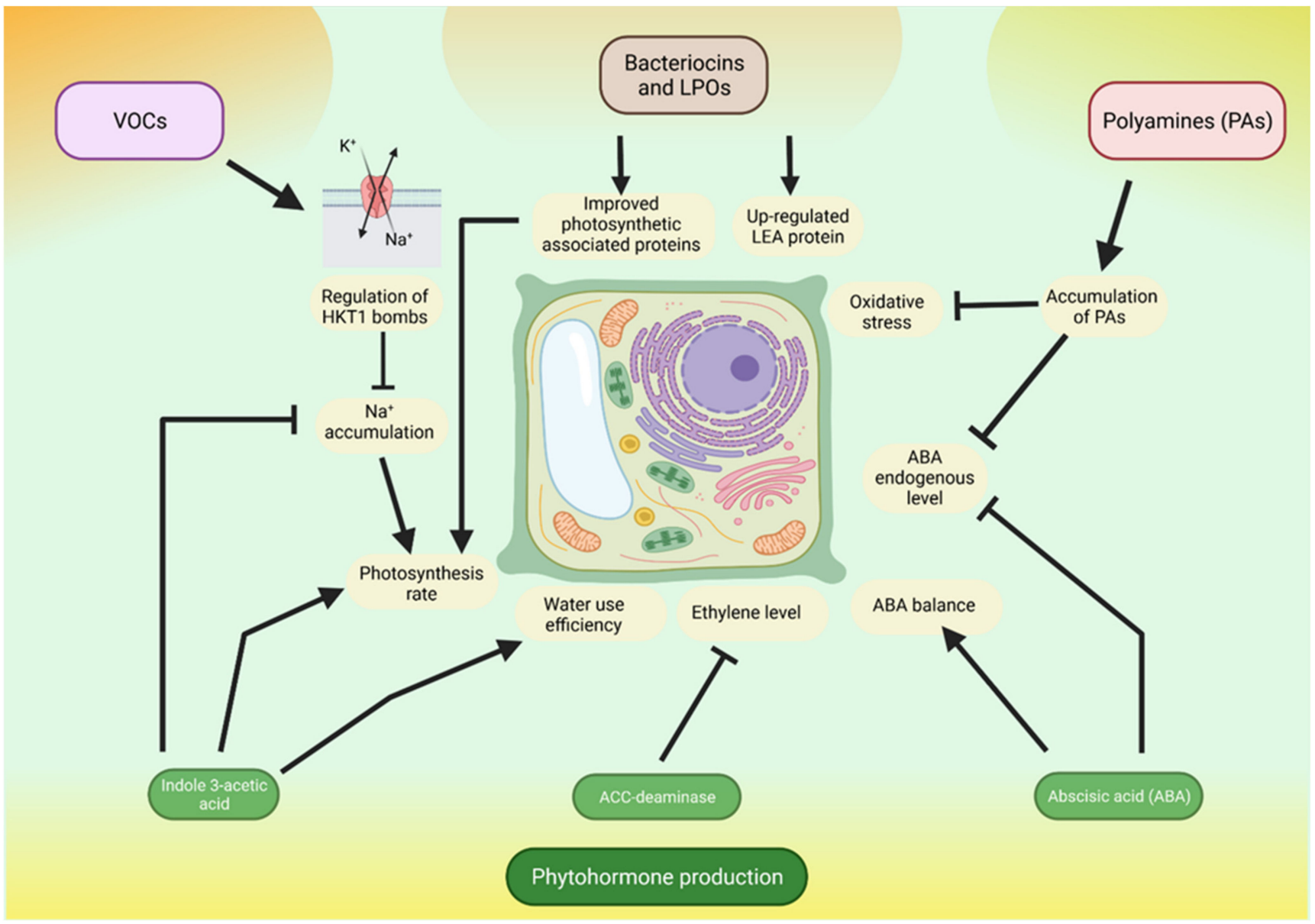

Figure 2. Molecules synthesized by PGPB involved in plant salinity tolerance.

\subsubsection{Indole-3-Acetic Acid}

IAA is the major auxin, which plays an important role in plant growth and development. Rhizobacteria can produce this metabolite by multiple synthesis pathways, most of which are L-tryptophan-dependent, which is present in root exudates [1,17]. The IAA hormone is involved in many vegetal processes, including cell division, elongation, differentiation, apical dominance, phototropism, and gravitropism [34,77,78]. At optimal levels, IAA may result in beneficial effects, but excessive amounts of this auxin can cause toxicity, as has been revealed by assessing the action mode of some phytopathogens [1,78]. Several studies have shown that the foliar application of exogenous IAA to various crops (maize, sorghum, and pea plants) induced alleviation of salt stress, through the modulation of photosynthesis rate, water use efficiency, $\mathrm{Na}^{+}$accumulation, or weight measurements $[58,79,80]$. This higher auxin content may contribute to maintaining root and leaf growth, which are important limiting factors under this abiotic stress condition.

Furthermore, the use of auxin-producing PGPB has been shown to minimise crop yield loss due to salinity. Yao et al., [67] have reported that salt-stressed cotton plants inoculated with IAA-producing P. putida increased in growth parameters with IAA content. The auxin content in shoots and roots of Arachis hypogaea L. plants was increased through the application of IAA-producing PGPB strains under salinity $(100 \mathrm{mM} \mathrm{NaCl})$, whose effects also positively affected various growth parameters [66]. In addition, the inoculation of saltstressed wheat plants with a salt-tolerant and IAA-producing Azospirillum strain exhibited enhancements in production parameters, including weight, chlorophyll, and micronutrient concentration [81]. The inoculation of salt-stressed wheat plants with Streptomyces (with the ability to produce IAA) also improved growth and development parameters [82]. 
In this sense, it has been shown that there is a correlation between bacterial IAA production and plant hormone status modification, which has positive effects on plant growth and development (Figure 2). Thus, both the use of exogenous IAA and inoculation with an IAA-deficient mutant (A. brasilense Sp245 indole pyruvate decarboxylase -ipdCmutant, generating only $10 \%$ of wild-type auxin production), showed that the growth response of Phaseolus vulgaris L. roots is related to a differential response to the bacterially produced auxin, in terms of root dry weight, nodule number, and the number of basal roots formed during germination [83].

\subsubsection{Ethylene (ACC-Deaminase)}

Ethylene is commonly known as a stress hormone, due to its synthesis in response to abiotic and biotic stress in plants [77]. This organic compound is regarded as an inhibitor of root growth and formation, also negatively influencing plant development as a whole [35,42]. Aminocyclopropane-1-carboxylate (ACC) is the precursor of ethylene biosynthesis, which can be transported specifically to stressed organs, where is converted into ethylene by the ACC oxidase enzyme [42,77]. PGPB influence the ethylene cycle in plants by inhibiting its production, which happens because rhizobacteria can secrete ACC deaminase, an enzyme which converts ACC into ammonia and $\alpha$-ketobutyrate; possible sources of carbon and nitrogen for bacteria [1,34]. In this context, ACC deaminase-containing PGPB may mitigate stress symptoms and boost plant development, by reducing the levels of this stress hormone and preventing the associated growth inhibition (Figure 2) [34,35,84].

Many studies have shown that ACC deaminase-producing bacteria can diminish the ethylene inhibition due to salinity. Maize inoculated with Pseudomonas and Enterobacter strains under saline conditions demonstrated that ACC deaminase synthesized by these bacteria led to improvements in plant growth parameters and nutrient absorption, such as higher $\mathrm{K}^{+} / \mathrm{Na}^{+}$ratios and NPK uptake [85]. Barnawal et al. [84] have reported a correlation between the protection of Trigonella plants against osmotic stress and reduced levels of ACC, due to inoculation with ACC deaminase-containing rhizobacteria (Bacillus and Ensifer), which also generated improvements in growth and plant-microbe interaction. Achromobacter piechaudii inoculation increased the nutrient uptake ( $\mathrm{P}$ and $\mathrm{K})$, as well as the fresh and dry weights of tomato seedlings grown in the presence of up to $172 \mathrm{mM}$ $\mathrm{NaCl}$ salt, and diminished ethylene production [86]. Three ACC deaminase-producing halotolerant bacteria (Brevibacterium, Bacillus, and Zhihengliuela) have been evaluated, in terms of improving red pepper growth under salt stress. Inoculation with these strains reduced ethylene production and enhanced plant development and nutrient acquisition [87]. The correlation between ACC deaminase production and protection against salt stress has been demonstrated in various reports. Thus, the inoculation of groundnut plants with an ACC deaminase-producing $P$. fluorescens strain enhanced their saline resistance and the yield of the plant, as compared with other strains lacking this activity [88]. In this sense, Orozco-Mosqueda et al. [51] and Ali et al. [89] have reported that ACC deaminase-deficient mutants (mutated at $a c d S$ ) inoculated on salt-stressed tomato plants performed worse, in terms of different production parameters, compared to wild-type strains.

Furthermore, there exist microbes which are capable of producing both IAA and ACC deaminase. As previously noted, IAA induces cell division and root growth, and the ACC deaminase produced by these bacteria hydrolyse the excess ACC, as well as promoting plant development $[1,35]$. Therefore, the combined action of both phytohormones can also help the plant to cope with adverse environmental conditions. For example, IAA- and ACC deaminase-producing Pantoea dispersa led to improved production parameters in salt-affected Cicer arietinum L. plants $(150 \mathrm{mM} \mathrm{NaCl})$. These effects were associated with a higher $\mathrm{K}^{+} / \mathrm{Na}^{+}$ratio, chlorophyll content, and relative leaf water content [90].

\subsubsection{Abscisic Acid (ABA)}

Abscisic acid (ABA) is another phytohormone involved in the plant response to abiotic and biotic stresses, mainly in protection against drought, salt stress, and toxic metals [91]. 
Under osmotic stress, ABA is produced in roots, and then can be translocated into leaves. It is involved in stomatal closure (reducing transpiration and maintaining water potential), the growth and emergence of roots (enhancing water uptake), and ion homeostasis [77,91]. Many PGPB can alter the ABA status in plants, acting as modulators of plant ABA content and, thus, allowing for the management of salt stress.

Some reports have exhibited that PGPB inoculation prevents ABA accumulation in plants (Figure 2). According to Yao et al. [67], cotton plants inoculated with P. putida Rs198 showed biomass enhancements and salt tolerance, induced by higher nutrient uptake and lower ABA production. In this sense, the inoculation of cucumber plants with Burkholderia, Promicromonospora, and Acinetobacter strains under salt and drought stress were revealed to be effective, with consequent increases in biomass, chlorophyll, water, and ion content. These treated plants also presented down-regulation of ABA, compared with uninoculated controls [92]. Additionally, Belimov et al. [93] conducted inoculation trials in tomato plants (using wild-type and negative mutants in ABA), with two ABA metabolizing rhizobacteria, in which it was observed that microbial inoculation decreased ABA concentration in roots and leaves, and altered plant development under saline conditions. Further, B. aryabhattai ATL29 and A. woluwensis ATL43 strains inoculated on salt-stressed soybean plants caused an enhancement in plant growth productive parameters, as associated with a reduction in ABA endogenous levels and the expression of GmNARK genes (related to the induction of ABA production) [94]. Finally, K. rhizophila Y1 inoculation protected maize from salt stress by regulating plant hormones: IAA (positively) and ABA (negatively). This study indicated that strain $\mathrm{Y} 1$ inoculation reduced ABA content markedly, in comparison with non-inoculated treatments, under salt stress treatment; these results being associated with the down-regulation of ZmNCED1 (the key gene for ABA synthesis) [63].

On the other hand, other studies have found that PGPB treatments improved ABA content in plants (Figure 2). Thus, Salomon et al. [95] have indicated that Bacillus and Pseudomonas strains (ABA-producing) act as stress alleviators in Vitis vinifera L., by inducing ABA synthesis and, so, reducing water losses. In another report, Cohen et al. [96] proposed that an ABA-producing Azospirillum lipoferum strain reversed the negative effects caused by osmotic stress in maize plants, even using ABA synthesis inhibitors. These results were correlated with ABA levels assessed by GC-EIMS. Furthermore, inoculation of maize plants with $B$. pumilis positively modulated the ABA content in leaves, while increases in water content, photosynthetic pigments, and osmotic potential were also recorded. This established the great potential of this bacterium for formulations to alleviate osmotic stress [97]. In this way, the evidence seems to indicate that PGPB are capable of modifying ABA levels, optimizing their function and regulation (which are already complex), while presenting different levels, according to the stage of development of the plant $[98,99]$.

\subsection{Other Molecules Synthesized by Rhizobacteria}

Certain bacterial mechanisms for modulating salt stress in plants are related to the secretion of extracellular molecules, such as volatile organic compounds or other organic compounds [1,34]. These substances act as inter-organismal signals, which affect plant behaviour by manipulating response pathways and regulatory functions, eliciting positive effects against stress conditions $[100,101]$, and several species are able to produce some which can alleviate osmotic and salinity stress (Table 2).

\subsubsection{Volatile Organic Compounds (VOCs)}

Volatile Organic Compounds (VOCs) are carbon-containing chemical substances with low molecular masses and boiling points, which can be emitted by rhizobacteria [1,79]. It has been reported that microbial volatiles can induce resistance to diseases and stimulate plant growth $[79,102]$. Other studies have indicated the effect of these substances in relieving salt stress in plants (Figure 2). The application of a putative $P$. simiae VOCs blend to soybean (under $100 \mathrm{mM} \mathrm{NaCl}$ ) decreased the $\mathrm{Na}^{+}$concentration in roots, and increased proline and chlorophyll content. Molecular analysis confirmed that this effect 
was induced by protein transcription changes [64]. Vaishnav et al. [103] has also found that two VOCs-namely, 4-nitroguaiacol and quinoline-promote soybean seed germination under $100 \mathrm{mM} \mathrm{NaCl}$ stress. Accordingly, Mentha x piperita L. plants grown under different $\mathrm{NaCl}$ levels (0 to $100 \mathrm{mM}$ ) were exposed to B. amyloliquefaciens GB03 VOCs (acetoin being the main one). This counteracted the negative effects of salinity, also causing a reduction in the endogenous levels of ABA in the plant [104].

\subsubsection{Polyamines}

Polyamines (PAs) are aliphatic amines with great antioxidant potential, which play an important role in plant development and abiotic stress response, by regulating antioxidant enzymes and genetic activities, as well as ROS homeostasis (Figure 2). Spermidine, spermine, and putrescine are the most significant polyamines $[1,101]$. It has been shown that exogenous PA application can induce tolerance to salinity, but more exhaustive studies of the effects on plants of the PAs secreted by PGPR are necessary. For example, spermidine secreted by B. amyloliquefaciens SQR9 caused a decrease in the effects of oxidative damage, a reduction of $\mathrm{Na}^{+}$toxicity, and an inhibition of ABA accumulation in Zea mays L. plants. These resulted in plant salt tolerance enhancement, which was confirmed through the construction of mutants $[105,106]$. Moreover, tomato plants grown under osmotic stress and inoculated with B. megaterium TG1-E1 accumulated a higher level of arginine, a precursor in the synthesis of polyamines (e.g., spermidine, spermine, or putrescine) [107].

\subsubsection{Bacteriocins and Lipo-Chito oligosaccharides}

Bacteriocins are ribosomally synthesized peptides secreted by bacteria, which are bactericidal and/or bacteriostatic against organisms closely related to the producer, and active at low concentrations [1,108]. These molecules are used as a competitive advantage in the ecological niche. The use of bacteriocins, such as Thuricin, has been focused in the food industry and medicines, but also has agricultural potential [108]. Lipo-chitooligosaccharides (LCOs) are molecules produced by microbes that trigger their symbiotic interactions with plants [109]. Among them, Nod-factors (NFs) are secreted by rhizobacteria in response to flavonoids in root exudates, which initiate nodule formation [1,110]. For example, LCOs extracted from $B$. diazoefficiens USDA 110 and from $R$. tropici CIAT 889, in conjunction with various rhizobacterial strains (Bradyrhizobium and Azospirullum), have been shown to enhance grain quality and nodule formation in soybean [111]. Furthermore, NFs can positively affect plant growth, even under abiotic stresses (Figure 2) [110,112,113]. Thuricin 17 (Th17), isolated from B. thuringiensis NEB17, has been shown to be a plant growth promoter under saline stress conditions, applied alone or in conjunction with Bradyrhizobium japonicum 532C LCOs. Brassica napus L. plants treated with Th17 showed a positive response under saline and temperature stress conditions, causing a higher biomass production and root development [113]. In this sense, the application of B. thuringiensis NEB17 Th17 and B. japonicum 532C LCOs to salt-stressed soybean (100 mM NaCl) altered the plant proteome, by positively regulating proteins involved in photosynthesis, metabolism, and stress-related pathways, such as: PEP carboxylase, rubisco oxygenase large subunit, glutathione-S-transferase (with antioxidant activity), and LEA proteins (involved in cellular dehydration tolerance) [110]. Thus, Th17 and LCO can manipulate the plant proteome profile and improve its physiological tolerance to salinity [110,112]. 
Table 2. PGPB producing molecules involved in tolerance to salinity stress.

\begin{tabular}{|c|c|c|c|c|}
\hline Bacteria & Plant & Mechanism & Effect & Reference \\
\hline \multicolumn{5}{|c|}{ Synthesis of phytohormones } \\
\hline Pseudomonas putida & Gossypium hirsutum L. & $\begin{array}{c}\text { Hormonal changes (IAA } \\
\text { and ABA) }\end{array}$ & $\begin{array}{c}\text { Increased germination rate, } \\
\text { productivity variables, and } \\
\text { nutrient content }\end{array}$ & [67] \\
\hline $\begin{array}{l}\text { Brachybacterium sp., } \\
\text { Brevibacterium sp. and } \\
\text { Haererohalobacter sp. }\end{array}$ & Arachis hypogaea L. & $\begin{array}{l}\text { Water homeostasis and } \\
\text { IAA plant accumulation }\end{array}$ & $\begin{array}{l}\text { Higher productivity variables } \\
\text { and nutrient content }\end{array}$ & {$[66]$} \\
\hline Azospirillum lipoferum & Triticum aestivum L. & $\begin{array}{l}\text { IAA production and } \mathrm{N}_{2} \\
\text { fixation }\end{array}$ & $\begin{array}{l}\text { Enhanced plant weight and } \\
\text { chlorophyll content }\end{array}$ & [81] \\
\hline Streptomyces sp. & Triticum aestivum $\mathrm{L}$. & $\begin{array}{l}\text { IAA and siderophore } \\
\text { production }\end{array}$ & $\begin{array}{l}\text { Increased plant germination } \\
\text { rate, length, weight, and } \\
\text { nutritional content }\end{array}$ & [82] \\
\hline $\begin{array}{l}\text { Azospirillum brasilense } \\
\text { and Rhizobium etli }\end{array}$ & Phaseolus vulgaris L. & IAA production & $\begin{array}{l}\text { Higher root weight, and } \\
\text { number of roots and nodules }\end{array}$ & [83] \\
\hline $\begin{array}{l}\text { Pseudomonas fluorescens } \\
\text { and Enterobacter } \\
\text { aerogenes }\end{array}$ & Zea mays L. & $\begin{array}{l}\text { ACC deaminase } \\
\text { production }\end{array}$ & $\begin{array}{c}\text { Increased plant height, } \\
\text { biomass, } \mathrm{K}^{+} / \mathrm{Na}^{+} \text {ratio, and } \\
\text { NPK uptake }\end{array}$ & [85] \\
\hline $\begin{array}{l}\text { Bacillus subtilis and } \\
\text { Ensifer meliloti }\end{array}$ & $\begin{array}{c}\text { Trigonella } \\
\text { foenum-graecum L. }\end{array}$ & $\begin{array}{l}\text { ACC deaminase } \\
\text { production }\end{array}$ & $\begin{array}{l}\text { Improved plant weight with } \\
\text { lower ACC concentration }\end{array}$ & [84] \\
\hline Achromobacter piechaudii & Solanum lycopersicum L. & $\begin{array}{l}\text { ACC deaminase } \\
\text { production }\end{array}$ & $\begin{array}{c}\text { Increased fresh and dry } \\
\text { weight, and } \mathrm{P} \text { and } \mathrm{K} \text { uptake }\end{array}$ & [86] \\
\hline $\begin{array}{l}\text { Brevibacterium iodinum, } \\
\text { Bacillus licheniformis, } \\
\text { and Zhihengliuela alba }\end{array}$ & Capsicum annuum L. & $\begin{array}{l}\text { ACC deaminase } \\
\text { production }\end{array}$ & $\begin{array}{l}\text { Higher biomass and nutrient } \\
\text { uptake }\end{array}$ & [87] \\
\hline Pseudomonas fluorescens & Arachis hypogaea L. & $\begin{array}{l}\text { ACC deaminase } \\
\text { production }\end{array}$ & $\begin{array}{l}\text { Increased seedling weight, } \\
\text { height, and germination }\end{array}$ & [88] \\
\hline Pseudomonas sp. & Solanum lycopersicum L. & $\begin{array}{c}\text { Accumulation of } \\
\text { osmoprotectans (trehalose) } \\
\text { and ACC deaminase } \\
\text { production }\end{array}$ & $\begin{array}{l}\text { Higher root and shoot length, } \\
\text { total dry weight, and } \\
\text { chlorophyll content }\end{array}$ & [57] \\
\hline $\begin{array}{c}\text { Pseudomonas fluorescens } \\
\text { and Pseudomonas } \\
\text { migulae }\end{array}$ & Solanum lycopersicum L. & $\begin{array}{l}\text { ACC deaminase } \\
\text { production }\end{array}$ & $\begin{array}{l}\text { Higher biomass, chlorophyll } \\
\text { content, and number of } \\
\text { flowers and buds }\end{array}$ & [89] \\
\hline Pantoea dispersa & Cicer arietinum $\mathrm{L}$. & $\begin{array}{l}\text { IAA and ACC deaminase } \\
\text { production }\end{array}$ & $\begin{array}{l}\text { Improved productivity } \\
\text { parameters, } \mathrm{K}^{+} / \mathrm{Na}^{+} \text {ratio, and } \\
\text { water and chlorophyll content }\end{array}$ & [90] \\
\hline $\begin{array}{l}\text { Burkholdera cepacian, } \\
\text { Promicromonospora sp. } \\
\text { and Acinetobacter } \\
\text { calcoaceticus }\end{array}$ & Cucumis sativus L. & $\begin{array}{l}\text { Downregulation of ABA } \\
\text { genes }\end{array}$ & $\begin{array}{l}\text { Increased biomass, and } \\
\text { chlorophyll, water, and ion ( } \mathrm{K} \\
\text { and } \mathrm{P}) \text { content }\end{array}$ & [92] \\
\hline $\begin{array}{l}\text { Rhodococcus sp. and } \\
\text { Novosphingobium sp. }\end{array}$ & Solanum lycopersicum L. & Metabolizing ABA & $\begin{array}{c}\text { Decreased ABA concentration } \\
\text { in roots and leaves, and altered } \\
\text { plant development }\end{array}$ & [93] \\
\hline $\begin{array}{l}\text { Bacillus aryabhattai and } \\
\text { Arthrobacter woluwensis }\end{array}$ & Glycine $\max \mathrm{L}$. & $\begin{array}{c}\text { Reduction in ABA } \\
\text { endogenous levels and } \\
\text { downregulation of ABA } \\
\text { genes }\end{array}$ & $\begin{array}{l}\text { Increased fresh and dry } \\
\text { weight, length, and } \\
\text { chlorophyll content }\end{array}$ & [94] \\
\hline Kocuria rhizophila & Zea mays L. & $\begin{array}{l}\text { Transcriptional changes in } \\
\text { ion transporter genes (HKT } \\
\text { and NHX-type) and } \\
\text { hormonal changes (IAA } \\
\text { and ABA) }\end{array}$ & $\begin{array}{c}\text { Decreased } \mathrm{Na}^{+} \text {accumulation } \\
\text { and increased productivity } \\
\text { parameters }\end{array}$ & {$[63]$} \\
\hline $\begin{array}{c}\text { Bacillus licheniformis } \\
\text { and Pseudomonas } \\
\text { fluorescens }\end{array}$ & Vitis vinifera $\mathrm{L}$. & $\begin{array}{l}\text { ABA production and } \\
\text { accumulation in plants }\end{array}$ & $\begin{array}{l}\text { Diminished plant water loss } \\
\text { rate }\end{array}$ & [95] \\
\hline
\end{tabular}


Table 2. Cont

\begin{tabular}{|c|c|c|c|c|}
\hline Bacteria & Plant & Mechanism & Effect & Reference \\
\hline Azospirillum lipoferum & Zea mays L. & $\begin{array}{l}\text { ABA, IAA, and gibberellins } \\
\text { production }\end{array}$ & $\begin{array}{l}\text { Reversed negative effects } \\
\text { caused by osmotic stress }\end{array}$ & [96] \\
\hline Bacillus pumilis & Zea mays L. & $\begin{array}{l}\text { ABA production and } \\
\text { accumulation in leaves }\end{array}$ & $\begin{array}{l}\text { Increased water content, } \\
\text { photosynthetic pigments, and } \\
\text { osmotic potential }\end{array}$ & [97] \\
\hline \multicolumn{5}{|c|}{ Other molecules synthesized by rhizobacteria } \\
\hline Pseudomonas simiae & Glycine $\max \mathrm{L}$. & $\begin{array}{l}\text { Transcriptional changes in } \\
\text { phosphatase activity, } \\
\text { accumulation of } \\
\text { osmoprotectans (proline), } \\
\text { and VOCs production } \\
\text { VOC production and }\end{array}$ & $\begin{array}{l}\text { Higher weight and length, and } \\
\qquad \mathrm{K}^{+} / \mathrm{Na}^{+} \text {ratio }\end{array}$ & [64] \\
\hline Pseudomonas psimiae & Glycine max L. & $\begin{array}{l}\text { transcriptional changes in } \\
\text { phosphatase activity }\end{array}$ & Promoted seed germination & {$[103]$} \\
\hline $\begin{array}{l}\text { Bacillus } \\
\text { amyloliquefaciens }\end{array}$ & Mentha $\times$ piperita $\mathrm{L}$. & $\begin{array}{l}\text { VOCs production and } \\
\text { reduction of ABA } \\
\text { endogenous levels }\end{array}$ & $\begin{array}{l}\text { Higher total chlorophyll } \\
\text { content, and better } \\
\text { morphological characteristics }\end{array}$ & [104] \\
\hline $\begin{array}{l}\text { Bacillus } \\
\text { amyloliquefaciens }\end{array}$ & Zea mays L. & $\begin{array}{l}\text { Polyamine production } \\
\text { (spermidine) }\end{array}$ & $\begin{array}{l}\text { Decreased oxidative damage } \\
\text { and } \mathrm{Na}^{+} \text {toxicity, and inhibiton } \\
\text { of } \mathrm{ABA} \text { accumulation in plants }\end{array}$ & {$[105,106]$} \\
\hline Bacillus megaterium & Solanum lycopersicum L. & $\begin{array}{l}\text { Production of polyamine } \\
\text { precursors }\end{array}$ & Osmotic stress resistance & [107] \\
\hline $\begin{array}{c}\text { Bradyrhizobium } \\
\text { japonicum and Bacillus } \\
\text { thuringiensis }\end{array}$ & Brassica napus L. & $\begin{array}{l}\text { Lipo-chitooligosaccharide } \\
\text { and bacteriocin production }\end{array}$ & $\begin{array}{l}\text { Affected plant growth, } \\
\text { architecture, and biomass }\end{array}$ & [113] \\
\hline $\begin{array}{l}\text { Bradyrhizobium } \\
\text { japonicum and Bacillus } \\
\text { thuringiensis }\end{array}$ & Glycine max L. & $\begin{array}{l}\text { Lipo-chitooligosaccharide } \\
\text { and bacteriocin production }\end{array}$ & $\begin{array}{l}\text { Changes in the proteome } \\
\text { during seed germination }\end{array}$ & [110] \\
\hline
\end{tabular}

\section{Conclusions}

Soil salinity is one of the main causes of abiotic stress in plants, as it generates not only environmental, but also economic and social problems. Crop yields can be reduced by the effects of salinity in plants (e.g., osmotic stress, ion toxicity, nutrient deficiency, and oxidative stress) and soils (loss of structure and fertility). In this sense, the use of plant growth-promoting bacteria (PGPB) has been reported as a sustainable and cost-effective alternative to increase plant tolerance to salt stress. Stress adaptation of plants is induced by the microbiota, through: (i) changes in plant hormonal balance (e.g., IAA and ABA production, or inhibition of ethylene synthesis); (ii) the release of extracellular compounds that act as chemical signals for the plant (e.g., LCOs, PAs, and/or VOCs), or enhancers that improve the soil conditions for plant development (e.g., EPS or Bacteriocins); (iii) regulating the internal ionic content of the plant (e.g., inducing ion transporters or regulating the exchange of macro and micronutrients); and (iv) facilitating the synthesis of osmoprotectant compounds that reduce osmotic stress (e.g., soluble sugars, proline, betaine, or trehalose).

Despite the studies carried out on these mechanisms to date, there exist other beneficial effects of soil microbiota that remain unknown, making it necessary to identify them, in order to optimise the use of PGPB in agronomic systems. Moreover, it is important to bear in mind that the action of these mechanisms is not individual, but that the same microorganism may induce different effects in the plant.

Therefore, the potential that PGPB provide is an incalculable resource favouring the salt tolerance and, thereby, reducing the effects of soil salinity in crops. In this line, many studies have shown that inoculation with halotolerant bacteria can lead to salinity alleviation in plants, but not all of them have investigated the mechanisms underlying these effects. Furthermore, the range of microorganisms capable of growing in saline conditions and promoting plant development is very wide. For all of these reasons, there exists a need 
for a deeper understanding and knowledge of plant-microorganism interactions and the PGPB mechanisms which mitigate salt stress in plants.

Author Contributions: Conceptualization, J.D.F.-F. and R.R.; methodology, M.A.-C.; investigation, M.A.-C. and J.D.F.-F.; data curation, R.R.; writing-original draft preparation, M.A.-C.; writingreview and editing, J.D.F.-F. and R.R.; supervision, R.R.; funding acquisition, R.R. All authors have read and agreed to the published version of the manuscript.

Funding: M.A.-C. is the recipient of a pre-doctoral fellowship from University of Salamanca; J.D.F.-F. is currently a recipient of post-doctoral Marie Skłodowska-Curie Fellowship No. 101003373. This work was supported by Grants PID2019-109960RB-100 from MCIN (Spanish Ministry of Science and Innovation) and Strategic Research Programs for Units of Excellence from Junta de Castilla y León (CLU-2O18-04).

Conflicts of Interest: The authors declare no conflict of interest.

\section{References}

1. Ilangumaran, G.; Smith, D.L. Plant growth promoting rhizobacteria in amelioration of salinity stress: A systems biology perspective. Front. Plant Sci. 2017, 8, 1768. [CrossRef] [PubMed]

2. Mukhopadhyay, R.; Sarkar, B.; Jat, H.S.; Sharma, P.C.; Bolan, N.S. Soil salinity under climate change: Challenges for sustainable agriculture and food security. J. Environ. Manag. 2020, 280, 111736. [CrossRef]

3. Corwin, D.L. Climate change impacts on soil salinity in agricultural areas. Eur. J. Soil Sci. 2021, 72, 842-862. [CrossRef]

4. Zaman, M.; Shahid, S.A.; Heng, L. Guideline for Salinity Assessment, Mitigation and Adaptation Using Nuclear and Related Techniques; Springer: Berlin, Germany, 2018; ISBN 9783319961897.

5. Hayat, K.; Bundschuh, J.; Jan, F.; Menhas, S.; Hayat, S.; Haq, F.; Shah, M.A.; Chaudhary, H.J.; Ullah, A.; Zhang, D.; et al. Combating soil salinity with combining saline agriculture and phytomanagement with salt-accumulating plants. Crit. Rev. Environ. Sci. Technol. 2020, 50, 1085-1115. [CrossRef]

6. Jamil, A.; Riaz, S.; Ashraf, M.; Foolad, M.R. Gene expression profiling of plants under salt stress. CRC. Crit. Rev. Plant Sci. 2011, 30, 435-458. [CrossRef]

7. Shrivastava, P.; Kumar, R. Soil salinity: A serious environmental issue and plant growth promoting bacteria as one of the tools for its alleviation. Saudi J. Biol. Sci. 2015, 22, 123-131. [CrossRef]

8. Reginato, M.; Luna, V.; Papenbrock, J. Current knowledge about $\mathrm{Na}_{2} \mathrm{SO}_{4}$ effects on plants: What is different in comparison to $\mathrm{NaCl}$ ? J. Plant Res. 2021, 1, 1-21. [CrossRef]

9. Rasheed, F.; Anjum, N.A.; Masood, A.; Sofo, A.; Khan, N.A. The key roles of salicylic acid and sulfur in plant salinity stress tolerance. J. Plant Growth Regul. 2020, 1-14. [CrossRef]

10. Ayuso-Calles, M.; García-Estévez, I.; Jiménez-Gómez, A.; Flores-Félix, J.D.; Teresa Escribano-Bailón, M.; Rivas, R. Rhizobium laguerreae improves productivity and phenolic compound content of lettuce (Lactuca sativa L.) under saline stress conditions. Foods 2020, 9, 1166. [CrossRef]

11. Abrol, I.P.; Yadav, J.S.P.; Massoud, F.I. Salt-Affected Soils and Their Management, FAO Soils Bulletin 39, 1st ed.; Food \& Agriculture Organization of the United Nations: Rome, Italy, 1988; pp. 13-90.

12. FAO. Handbook for Saline Soil Management; Vargas, R., Pankova, E.I., Balyuk, S.A., Krasilnikov, P.V., Hasanhanova, G.M., Eds.; Food and Agriculture Organization of the United Nations: Rome, Italy; Lomonosov Moscow State University: Moscow, Russia, 2018; ISBN 978-92-5-130141-8.

13. Shahid, S.A.; Zaman, M.; Heng, L. Soil salinity: Historical perspectives and a world overview of the problem. In Guideline for Salinity Assessment, Mitigation and Adaptation Using Nuclear and Related Techniques; Springer International Publishing: Cham, Switzerland, 2018; pp. 43-53, ISBN 978-3-319-96190-3.

14. Minhas, P.S.; Ramos, T.B.; Ben-Gal, A.; Pereira, L.S. Coping with salinity in irrigated agriculture: Crop evapotranspiration and water management issues. Agric. Water Manag. 2020, 227, 105832. [CrossRef]

15. Meena, M.D.; Yadav, R.K.; Narjary, B.; Yadav, G.; Jat, H.S.; Sheoran, P.; Meena, M.K.; Antil, R.S.; Meena, B.L.; Singh, H.V.; et al. Municipal solid waste (MSW): Strategies to improve salt affected soil sustainability: A review. Waste Manag. 2019, 84, 38-53. [CrossRef] [PubMed]

16. Munns, R.; Tester, M. Mechanisms of Salinity Tolerance. Annu. Rev. Plant Biol. 2008, 59, 651-681. [CrossRef]

17. Etesami, H.; Adl, S.M. Can interaction between silicon and non-rhizobial bacteria benefit in improving nodulation and nitrogen fixation in salinity-stressed legumes? A review. Rhizosphere 2020, 15, 100229. [CrossRef]

18. Qadir, M.; Quillérou, E.; Nangia, V.; Murtaza, G.; Singh, M.; Thomas, R.J.; Drechsel, P.; Noble, A.D. Economics of salt-induced land degradation and restoration. Nat. Resour. Forum 2014, 38, 282-295. [CrossRef]

19. Agrawal, A.A.; Conner, J.K.; Stinchcombe, J.R. Evolution of plant resistance and tolerance to frost damage. Ecol. Lett. 2004, 7, 1199-1208. [CrossRef]

20. Deinlein, U.; Stephan, A.B.; Horie, T.; Luo, W.; Xu, G.; Schroeder, J.I. Plant salt-tolerance mechanisms. Trends Plant Sci. 2014, 19, 371-379. [CrossRef] 
21. Mushtaq, Z.; Faizan, S.; Gulzar, B. Salt stress, its impacts on plants and the strategies plants are employing against it: A review. J. Appl. Biol. Biotechnol. 2020, 8, 81-91. [CrossRef]

22. Safdar, H.; Amin, A.; Shafiq, Y.; Ali, A.; Yasin, R.; Shoukat, A.; Hussan, M.U.; Sarwar, M.I. A review: Impact of salinity on plant growth. Nat. Sci. 2019, 17, 34-40. [CrossRef]

23. Dodd, I.C.; Pérez-Alfocea, F. Microbial amelioration of crop salinity stress. J. Exp. Bot. 2012, 63, 3415-3428. [CrossRef]

24. Bano, A.; Fatima, M. Salt tolerance in Zea mays (L). following inoculation with Rhizobium and Pseudomonas. Biol. Fertil. Soils 2009, 45, 405-413. [CrossRef]

25. Talei, D.; Kadir, M.A.; Yusop, M.K.; Abdullah, M.P.; Valdiani, A. Salinity effects on macro and micronutrients uptake in medicinal plant King of Bitters (Andrographis paniculata Nees.). Plant Omics 2012, 5, 271-278.

26. Apel, K.; Hirt, H. Reactive Oxygen Species: Metabolism, Oxidative Stress, and Signal Transduction. Annu. Rev. Plant Biol. 2004, 55, 373-399. [CrossRef]

27. Upadhyay, S.K.; Singh, J.S.; Saxena, A.K.; Singh, D.P. Impact of PGPR inoculation on growth and antioxidant status of wheat under saline conditions. Plant Biol. 2012, 14, 605-611. [CrossRef]

28. Upadhyay, S.K.; Saxena, A.K.; Singh, J.S.; Singh, D.P. Impact of Native ST-PGPR (Bacillus pumilus; EU927414) on PGP Traits, Antioxidants Activities, Wheat Plant Growth and Yield under Salinity. Clim. Chang. Environ. Sustain. 2019, 7, 157. [CrossRef]

29. Jiménez-Gómez, A.; García-Estévez, I.; García-Fraile, P.; Escribano-Bailón, M.T.; Rivas, R. Increase in phenolic compounds of Coriandrum sativum L. after the application of a Bacillus halotolerans biofertilizer. J. Sci. Food Agric. 2020, 100, 2742-2749. [CrossRef]

30. Han, H.S.; Lee, K.D. Physiological Responses of Soybean-Inoculation of Bradyrhizobium japonicum with PGPR in Saline Soil Conditions. Seven 2005, 1, 216-221.

31. Goswami, D.; Dhandhukia, P.; Patel, P.; Thakker, J.N. Screening of PGPR from saline desert of Kutch: Growth promotion in Arachis hypogea by Bacillus licheniformis A2. Microbiol. Res. 2014, 169, 66-75. [CrossRef] [PubMed]

32. Chen, H.; Jiang, J. Osmotic adjustment and plant adaptation to environmental changes related to drought and salinity. Environ. Rev. 2010, 319, 309-319. [CrossRef]

33. Kim, Y.; Khan, A.L.; Waqas, M.; Lee, I.; Lee, I. Silicon Regulates Antioxidant Activities of Crop Plants under Abiotic-Induced Oxidative Stress: A Review. Front. Plant Sci. 2017, 8, 510. [CrossRef]

34. Egamberdieva, D.; Wirth, S.; Bellingrath-Kimura, S.D.; Mishra, J.; Arora, N.K. Salt-Tolerant Plant Growth Promoting Rhizobacteria for Enhancing Crop Productivity of Saline Soils. Front. Microbiol. 2019, 10, 2791. [CrossRef]

35. Arora, N.K.; Tewari, S.; Singh, S.; Lal, N.; Maheshwari, D.K. PGPR for protection of plant health under saline conditions. In Bacteria in Agrobiology: Stress Management; Maheshwari, D.K., Ed.; Springer: Berlin/Heidelberg, Germany, 2012; pp. 239-258, ISBN 978-3-642-23465-1.

36. Hooshdar, P.; Kermanshahi, R.K.; Ghadam, P.; Khosravi-darani, K. A Review on Production of Exopolysaccharide and Biofilm in Probiotics Like Lactobacilli and Methods of Analysis. Biointerface Res. Appl. Chem. 2020, 10, 6058-6075.

37. Gupta, P.; Diwan, B. Bacterial Exopolysaccharide mediated heavy metal removal: A Review on biosynthesis, mechanism and remediation strategies. Biotechnol. Rep. 2017, 13, 58-71. [CrossRef] [PubMed]

38. Martens, D.A.; Frankenberger, W.T. Decomposition of bacterial polymers in soil and their influence on soil structure. Biol. Fertil. Soils 1992, 13, 65-73. [CrossRef]

39. Rashid, M.I.; Mujawar, L.H.; Shahzad, T.; Almeelbi, T.; Ismail, I.M.I.; Oves, M. Bacteria and fungi can contribute to nutrients bioavailability and aggregate formation in degraded soils. Microbiol. Res. 2016, 183, 26-41. [CrossRef]

40. Kohler, J.; Caravaca, F.; Carrasco, L.; Rolda, A. Contribution of Pseudomonas mendocina and Glomus intraradices to aggregate stabilization and promotion of biological fertility in rhizosphere soil of lettuce plants under field conditions. Soil Use Manag. 2006, 22, 298-304. [CrossRef]

41. Qurashi, A.W.; Sabri, A.N. Bacterial exopolysaccharide and biofilm formation stimulate chickpea growth and soil aggregation under salt stress. Braz. J. Microbiol. 2012, 43, 1183-1191. [CrossRef] [PubMed]

42. Dodd, I.C.; Zinovkina, N.Y.; Safronova, V.I.; Belimov, A.A. Rhizobacterial mediation of plant hormone status. Ann. Appl. Biol. 2010, 157, 361-379. [CrossRef]

43. Ben Salah, I.; Albacete, A.; Messedi, D.; Gandour, M.; Martínez Andújar, C.; Zribi, K.; Martinez, V.; Abdelly, C.; Pérez-Alfocea, F. Hormonal responses of nodulated Medicago ciliaris lines differing in salt tolerance. Environ. Exp. Bot. 2013, 86, 35-43. [CrossRef]

44. Ilangumaran, G.; Schwinghamer, T.D.; Smith, D.L.; Smith, D.L. Rhizobacteria from Root Nodules of an Indigenous Legume Enhance Salinity Stress Tolerance in Soybean. Front. Sustain. Food Syst. 2021, 4, 308. [CrossRef]

45. Del Amor, F.M.; Cuadra-Crespo, P. Plant growth-promoting bacteria as a tool to improve salinity tolerance in sweet pepper. Funct. Plant Biol. 2012, 39, 82-90. [CrossRef]

46. Seema, K.; Mehta, K.; Singh, N. Studies on the effect of plant growth promoting rhizobacteria (PGPR) on growth, physiological parameters, yield and fruit quality of strawberry cv. chandler. J. Pharmacogn. Phytochem. 2018, 7, 383-387.

47. Upadhyay, S.K.; Singh, D.P. Effect of salt-tolerant plant growth-promoting rhizobacteria on wheat plants and soil health in a saline environment. Plant Biol. 2015, 17, 288-293. [CrossRef]

48. Porcel, R.; Aroca, R.; Ruiz-Lozano, J.M. Salinity stress alleviation using arbuscular mycorrhizal fungi. A review. Agron. Sustain. Dev. 2012, 32, 181-200. [CrossRef] 
49. Pinedo, I.; Ledger, T.; Greve, M.; Poupin, M.J. Burkholderia phytofirmans PsJN induces long-term metabolic and transcriptional changes involved in Arabidopsis thaliana salt tolerance. Front. Plant Sci. 2015, 6, 466. [CrossRef]

50. Ait-Barka, E.; Nowak, J.; Clément, C. Enhancement of chilling resistance of inoculated grapevine plantlets with a plant growthpromoting rhizobacterium, Burkholderia phytofirmans strain PsJN. Appl. Environ. Microbiol. 2006, 72, 7246-7252. [CrossRef] [PubMed]

51. Sziderics, A.H.; Rasche, F.; Trognitz, F.; Sessitsch, A.; Wilhelm, E. Bacterial endophytes contribute to abiotic stress adaptation in pepper plants (Capsicum annuum L.). Can. J. Microbiol. 2007, 53, 1195-1202. [CrossRef] [PubMed]

52. Rodríguez-Salazar, J.; Suárez, R.; Caballero-Mellado, J.; Iturriaga, G. Trehalose accumulation in Azospirillum brasilense improves drought tolerance and biomass in maize plants. FEMS Microbiol. Lett. 2009, 296, 52-59. [CrossRef] [PubMed]

53. Vardharajula, S.; Ali, S.Z.; Grover, M.; Reddy, G.; Bandi, V. Drought-tolerant plant growth promoting Bacillus spp.: Effect on growth, osmolytes, and antioxidant status of maize under drought stress. J. Plant Interact. 2011, 6, 1-14. [CrossRef]

54. Jha, Y.; Subramanian, R.B.; Patel, S. Combination of endophytic and rhizospheric plant growth promoting rhizobacteria in Oryza sativa shows higher accumulation of osmoprotectant against saline stress. Acta Physiol. Plant. 2011, 33, 797-802. [CrossRef]

55. Haroon, U.; Khizar, M.; Liaquat, F.; Ali, M.; Akbar, M.; Tahir, K.; Saira, S. Halotolerant Plant Growth-Promoting Rhizobacteria induce salinity tolerance in wheat by enhancing the expression of SOS genes. J. Plant Growth Regul. 2021. [CrossRef]

56. Sapre, S.; Gontia, I.; Sharad, M. Plant Growth—Promoting Rhizobacteria ameliorates salinity stress in pea (Pisum sativum). J. Plant Growth Regul. 2021. [CrossRef]

57. Orozco-Mosqueda, M.D.C.; Duan, J.; DiBernardo, M.; Zetter, E.; Campos-García, J.; Glick, B.R.; Santoyo, G. The production of ACC deaminase and trehalose by the plant growth promoting bacterium Pseudomonas sp. UW4 synergistically protect tomato plants against salt stress. Front. Microbiol. 2019, 10, 1392. [CrossRef] [PubMed]

58. Groppa, M.D.; Benavides, M.P.; Zawoznik, M.S. Root hydraulic conductance, aquaporins and plant growth promoting microorganisms: A revision. Appl. Soil Ecol. 2012, 61, 247-254. [CrossRef]

59. Marulanda, A.; Azcón, R.; Chaumont, F.; Ruiz-Lozano, J.M.; Aroca, R. Regulation of plasma membrane aquaporins by inoculation with a Bacillus megaterium strain in maize (Zea mays L.) plants under unstressed and salt-stressed conditions. Planta 2010, 232, 533-543. [CrossRef]

60. Gond, S.K.; Torres, M.S.; Bergen, M.S.; Helsel, Z.; White, J.F. Induction of salt tolerance and up-regulation of aquaporin genes in tropical corn by rhizobacterium Pantoea agglomerans. Lett. Appl. Microbiol. 2015, 60, 392-399. [CrossRef]

61. Zawoznik, M.S.; Ameneiros, M.; Benavides, M.P.; Vázquez, S.; Groppa, M.D. Response to saline stress and aquaporin expression in Azospirillum- inoculated barley seedlings. Appl. Microbiol. Biotechnol. 2011, 90, 1389-1397. [CrossRef] [PubMed]

62. Niu, S.Q.; Li, H.R.; Paré, P.W.; Aziz, M.; Wang, S.M.; Shi, H.; Li, J.; Han, Q.Q.; Guo, S.Q.; Li, J.; et al. Induced growth promotion and higher salt tolerance in the halophyte grass Puccinellia tenuiflora by beneficial rhizobacteria. Plant Soil 2016, 407, 217-230. [CrossRef]

63. Li, X.; Sun, P.; Zhang, Y.; Jin, C.; Guan, C. A novel PGPR strain Kocuria rhizophila Y1 enhances salt stress tolerance in maize by regulating phytohormone levels, nutrient acquisition, redox potential, ion homeostasis, photosynthetic capacity and stressresponsive genes expression. Environ. Exp. Bot. 2020, 174, 104023. [CrossRef]

64. Vaishnav, A.; Kumari, S.; Jain, S.; Varma, A.; Choudhary, D.K. Putative bacterial volatile-mediated growth in soybean (Glycine $\max$ L. Merrill) and expression of induced proteins under salt stress. J. Appl. Microbiol. 2015, 119, 539-551. [CrossRef]

65. Kohler, J.; Hernández, J.A.; Caravaca, F.; Roldán, A. Plant-growth-promoting rhizobacteria and arbuscular mycorrhizal fungi modify alleviation biochemical mechanisms in water-stressed plants. Funct. Plant Biol. 2008, 35, 141-151. [CrossRef]

66. Shukla, P.S.; Agarwal, P.K.; Jha, B. Improved Salinity Tolerance of Arachis hypogaea (L.) by the Interaction of Halotolerant Plant-Growth-Promoting Rhizobacteria. J. Plant Growth Regul. 2012, 31, 195-206. [CrossRef]

67. Yao, L.; Wu, Z.; Zheng, Y.; Kaleem, I.; Li, C. Growth promotion and protection against salt stress by Pseudomonas putida Rs-198 on cotton. Eur. J. Soil Biol. 2010, 46, 49-54. [CrossRef]

68. Rojas-Tapias, D.; Moreno-Galván, A.; Pardo-Díaz, S.; Obando, M.; Rivera, D.; Bonilla, R. Effect of inoculation with plant growth-promoting bacteria (PGPB) on amelioration of saline stress in maize (Zea mays). Appl. Soil Ecol. 2012, 61, 264-272. [CrossRef]

69. Hamdia, M.A.E.; Shaddad, M.A.K.; Doaa, M.M. Mechanisms of salt tolerance and interactive effects of Azospirillum brasilense inoculation on maize cultivars grown under salt stress conditions. Plant Growth Regul. 2004, 44, 165-174. [CrossRef]

70. Ashraf, M.; Hasnain, S.; Berge, O.; Mahmood, T. Inoculating wheat seedlings with exopolysaccharide-producing bacteria restricts sodium uptake and stimulates plant growth under salt stress. Biol. Fertil. Soils 2004, 40, 157-162. [CrossRef]

71. Talebi Atouei, M.; Pourbabaee, A.A.; Shorafa, M. Alleviation of Salinity Stress on Some Growth Parameters of Wheat by Exopolysaccharide-Producing Bacteria. Iran. J. Sci. Technol. Trans. A Sci. 2019, 43, 2725-2733. [CrossRef]

72. Kohler, J.; Hernández, J.A.; Caravaca, F.; Roldán, A. Induction of antioxidant enzymes is involved in the greater effectiveness of a PGPR versus AM fungi with respect to increasing the tolerance of lettuce to severe salt stress. Environ. Exp. Bot. 2009, 65, 245-252. [CrossRef]

73. Kumari, S.; Vaishnav, A.; Jain, S.; Varma, A.; Choudhary, D.K. Bacterial-Mediated Induction of Systemic Tolerance to Salinity with Expression of Stress Alleviating Enzymes in Soybean (Glycine max L. Merrill). J. Plant Growth Regul. 2015, 34, 558-573. [CrossRef]

74. Martínez, R.; Espejo, A.; Sierra, M.; Ortiz-Bernad, I.; Correa, D.; Bedmar, E.; López-Jurado, M.; Porres, J.M. Co-inoculation of Halomonas maura and Ensifer meliloti to improve alfalfa yield in saline soils. Appl. Soil Ecol. 2015, 87, 81-86. [CrossRef] 
75. Khalilpour, M.; Mozafari, V.; Abbaszadeh-dahaji, P. Scientia Horticulturae Tolerance to salinity and drought stresses in pistachio (Pistacia vera L.) seedlings inoculated with indigenous stress-tolerant PGPR isolates. Sci. Hortic. 2021, 289, 110440. [CrossRef]

76. Zhang, H.; Kim, M.S.; Sun, Y.; Dowd, S.E.; Shi, H.; Paré, P.W. Soil bacteria confer plant salt tolerance by tissue-specific regulation of the sodium transporter HKT1. Mol. Plant-Microbe Interact. 2008, 21, 737-744. [CrossRef]

77. Vaishnav, A.; Varma, A.; Tuteja, N.; Choudhary, D.K. PGPR-mediated amelioration of crops under salt stress. In Plant-Microbe Interaction: An Approach to Sustainable Agriculture; Choudhary, D.K., Varma, A., Tuteja, N., Eds.; Springer: Singapore, 2016; pp. 205-226, ISBN 978-981-10-2854-0.

78. Korasick, D.A.; Enders, T.A.; Strader, L.C. Auxin biosynthesis and storage forms. J. Exp. Bot. 2013, 64, 2541-2555. [CrossRef]

79. Bhattacharyya, D.; Garladinne, M.; Lee, Y.H. Volatile Indole Produced by Rhizobacterium Proteus vulgaris JBLS202 Stimulates Growth of Arabidopsis thaliana Through Auxin, Cytokinin, and Brassinosteroid Pathways. J. Plant Growth Regul. 2015, 34, 158-168. [CrossRef]

80. Azooz, M.M.; Shaddad, M.A.; Abdel-Latef, A.A. Leaf growth and $\mathrm{K}^{+} / \mathrm{Na}^{+}$ratio as an indication of the salt tolerance of three sorghum cultivars grown under salinity stress and IAA treatment. Acta Agron. Hung. 2004, 52, 287-296. [CrossRef]

81. El-Akhdar, I.A.; Elshikh, M.; Allam, N.G.; Kamal, F.; Staehelin, C. Evaluation of salt-tolerant Azospirillum spp and its role in improvement of wheat growth parameter. Environ. Biodivers. Soil Secur. 2019, 3, 15-17. [CrossRef]

82. Sadeghi, A.; Karimi, E.; Dahaji, P.A.; Javid, M.G.; Dalvand, Y.; Askari, H. Plant growth promoting activity of an auxin and siderophore producing isolate of Streptomyces under saline soil conditions. World J. Microbiol. Biotechnol. 2012, 28, 1503-1509. [CrossRef] [PubMed]

83. Remans, R.; Beebe, S.; Blair, M.; Manrique, G.; Tovar, E.; Rao, I.; Croonenborghs, A.; Torres-Gutierrez, R.; El-Howeity, M.; Michiels, J.; et al. Physiological and genetic analysis of root responsiveness to auxin-producing plant growth-promoting bacteria in common bean (Phaseolus vulgaris L.). Plant Soil 2008, 302, 149-161. [CrossRef]

84. Barnawal, D.; Maji, D.; Bharti, N.; Chanotiya, C.S.; Kalra, A. ACC Deaminase-Containing Bacillus subtilis reduces stress ethyleneinduced damage and improves mycorrhizal colonization and rhizobial nodulation in Trigonella foenum-graecum under Drought Stress. J. Plant Growth Regul. 2013, 32, 809-822. [CrossRef]

85. Nadeem, S.M.; Zahir, Z.A.; Naveed, M.; Arshad, M. Rhizobacteria containing ACC-deaminase confer salt tolerance in maize grown on salt-affected fields. Can. J. Microbiol. 2009, 55, 1302-1309. [CrossRef]

86. Mayak, S.; Tirosh, T.; Glick, B.R. Plant growth-promoting bacteria confer resistance in tomato plants to salt stress. Plant Physiol. Biochem. 2004, 42, 565-572. [CrossRef]

87. Siddikee, M.A.; Glick, B.R.; Chauhan, P.S.; Yim, W.J.; Sa, T. Enhancement of growth and salt tolerance of red pepper seedlings (Capsicum annuum L.) by regulating stress ethylene synthesis with halotolerant bacteria containing 1-aminocyclopropane-1carboxylic acid deaminase activity. Plant Physiol. Biochem. 2011, 49, 427-434. [CrossRef] [PubMed]

88. Saravanakumar, D.; Samiyappan, R. ACC deaminase from Pseudomonas fluorescens mediated saline resistance in groundnut (Arachis hypogea) plants. J. Appl. Microbiol. 2007, 102, 1283-1292. [CrossRef] [PubMed]

89. Ali, S.; Charles, T.C.; Glick, B.R. Amelioration of high salinity stress damage by plant growth-promoting bacterial endophytes that contain ACC deaminase. Plant Physiol. Biochem. 2014, 80, 160-167. [CrossRef]

90. Panwar, M.; Tewari, R.; Gulati, A.; Nayyar, H. Indigenous salt-tolerant rhizobacterium Pantoea dispersa (PSB3) reduces sodium uptake and mitigates the effects of salt stress on growth and yield of chickpea. Acta Physiol. Plant. 2016, 38, 1-12. [CrossRef]

91. Pliego, C.; Kamilova, F.; Lugtenberg, B. Bacteria in Agrobiology: Crop Ecosystems; Springer: Berlin, Germany, 2011; ISBN 9783642183577.

92. Kang, S.M.; Khan, A.L.; Waqas, M.; You, Y.H.; Kim, J.H.; Kim, J.G.; Hamayun, M.; Lee, I.J. Plant growth-promoting rhizobacteria reduce adverse effects of salinity and osmotic stress by regulating phytohormones and antioxidants in Cucumis sativus. J. Plant Interact. 2014, 9, 673-682. [CrossRef]

93. Belimov, A.A.; Dodd, I.C.; Safronova, V.I.; Dumova, V.A.; Shaposhnikov, A.I.; Ladatko, A.G.; Davies, W.J. Abscisic acid metabolizing rhizobacteria decrease ABA concentrations in planta and alter plant growth. Plant Physiol. Biochem. 2014, 74, 84-91. [CrossRef] [PubMed]

94. Khan, M.A.; Sahile, A.A.; Jan, R.; Asaf, S.; Hamayun, M.; Imran, M.; Adhikari, A.; Kang, S.; Kim, K.; Lee, I. Halotolerant bacteria mitigate the effects of salinity stress on soybean growth by regulating secondary metabolites and molecular responses. $B M C$ Plant Biol. 2021, 21, 1-15. [CrossRef] [PubMed]

95. Salomon, M.V.; Bottini, R.; de Souza Filho, G.A.; Cohen, A.C.; Moreno, D.; Gil, M.; Piccoli, P. Bacteria isolated from roots and rhizosphere of Vitis vinifera retard water losses, induce abscisic acid accumulation and synthesis of defense-related terpenes in in vitro cultured grapevine. Physiol. Plant. 2014, 151, 359-374. [CrossRef]

96. Cohen, A.C.; Travaglia, C.N.; Bottini, R.; Piccoli, P.N. Participation of abscisic acid and gibberellins produced by endophytic Azospirillum in the alleviation of drought effects in maize. Botany 2009, 87, 455-462. [CrossRef]

97. Yasmin, H.; Nosheen, A.; Naz, R.; Bano, A.; Keyani, R. L-tryptophan-assisted PGPR-mediated induction of drought tolerance in maize (Zea mays L.). J. Plant Interact. 2017, 12, 567-578. [CrossRef]

98. Seo, M.; Koshiba, T. Complex regulation of ABA biosynthesis in plants. Trends Plant Sci. 2002, 7, 41-48. [CrossRef]

99. Zhao, X.; Muhammad, N.; Zhao, Z.; Yin, K.; Liu, Z.; Wang, L.; Luo, Z.; Wang, L.; Liu, M. Molecular regulation of fruit size in horticultural plants: A review. Sci. Hortic. 2021, 288, 110353. [CrossRef] 
100. Smith, D.L.; Praslickova, D.; Ilangumaran, G. Inter-organismal signaling and management of the phytomicrobiome. Front. Plant Sci. 2015, 6, 722. [CrossRef] [PubMed]

101. Zhou, C.; Ma, Z.; Zhu, L.; Xiao, X.; Xie, Y.; Zhu, J.; Wang, J. Rhizobacterial strain Bacillus megaterium BOFC15 induces cellular polyamine changes that improve plant growth and drought resistance. Int. J. Mol. Sci. 2016, 17, 976. [CrossRef]

102. Farag, M.A.; Ryu, C.-M.; Sumner, L.W.; Paré, P.W. GC-MS SPME profiling of rhizobacterial volatiles reveals prospective inducers of growth promotion and induced systemic resistance in plants. Phytochemistry 2006, 67, 2262-2268. [CrossRef] [PubMed]

103. Vaishnav, A.; Kumari, S.; Jain, S.; Varma, A.; Tuteja, N.; Choudhary, D.K. PGPR-mediated expression of salt tolerance gene in soybean through volatiles under sodium nitroprusside. J. Basic Microbiol. 2016, 56, 1274-1288. [CrossRef] [PubMed]

104. Cappellari, R.; Banchio, E. Microbial Volatile Organic Compounds Produced by Bacillus amyloliquefaciens GB03 ameliorate the effects of salt stress in Mentha piperita principally through acetoin emission. J. Plant Growth Regul. 2020, 39, 764-775. [CrossRef]

105. Chen, L.; Liu, Y.; Wu, G.; Zhang, N.; Shen, Q.; Zhang, R. Beneficial Rhizobacterium Bacillus amyloliquefaciens SQR9 induces plant salt tolerance through spermidine production. Mol. Plant-Microbe Interact. 2017, 30, 423-432. [CrossRef]

106. Chen, L.; Liu, Y.; Wu, G.; Veronican Njeri, K.; Shen, Q.; Zhang, N.; Zhang, R. Induced maize salt tolerance by rhizosphere inoculation of Bacillus amyloliquefaciens SQR9. Physiol. Plant. 2016, 158, 34-44. [CrossRef]

107. Morcillo, R.J.L.; Juan, I.V.; Zhang, S.; Kaushal, R.; He, D.; Zi, H.; Liu, R.; Niehaus, K.; Handa, A.K.; Zhang, H. Plant transcriptome reprograming and bacterial extracellular metabolites underlying tomato drought resistance triggered by a beneficial soil bacteria. Metabolites. 2021, 11, 369. [CrossRef]

108. Nazari, M.; Smith, D.L. A PGPR-produced bacteriocin for sustainable agriculture: A review of Thuricin 17 characteristics and applications. Front. Plant Sci. 2020, 11, 916. [CrossRef]

109. Oldroyd, G.E.D. Speak, friend, and enter: Signalling systems that promote beneficial symbiotic associations in plants. Nat. Rev. Microbiol. 2013, 11, 252-263. [CrossRef]

110. Subramanian, S.; Ricci, E.; Souleimanov, A.; Smith, D.L. A proteomic approach to lipo-chitooligosaccharide and thuricin 17 effects on soybean germinationunstressed and salt stress. PLoS ONE 2016, 11, e0160660. [CrossRef] [PubMed]

111. Moretti, L.G.; Alexandre, C.; Crusciol, C.; Bossolani, J.W. Bacterial consortium and microbial metabolites increase grain quality and soybean. J. Soil Sci. Plant Nutr. 2020, 20, 1923-1934. [CrossRef]

112. Subramanian, S.; Souleimanov, A.; Smith, D.L. Proteomic studies on the effects of lipo-chitooligosaccharide and thuricin 17 under unstressed and salt stressed conditions in Arabidopsis thaliana. Front. Plant Sci. 2016, 7, 1314. [CrossRef]

113. Schwinghamer, T.; Souleimanov, A.; Dutilleul, P.; Smith, D. Supplementation with solutions of lipo-chitooligosacharide Nod Bj V (C18:1, MeFuc) and thuricin 17 regulates leaf arrangement, biomass, and root development of canola (Brassica napus [L.]). Plant Growth Regul. 2016, 78, 31-41. [CrossRef] 